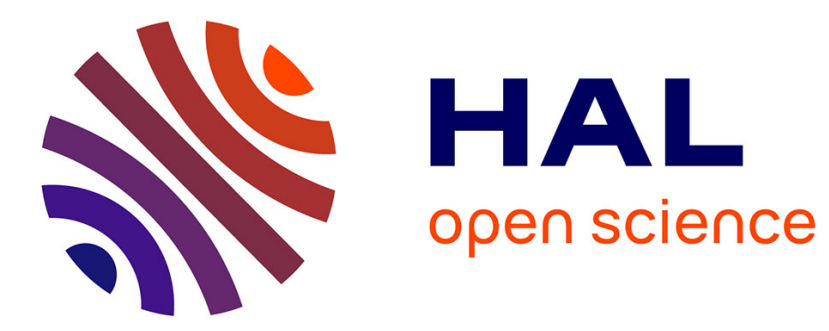

\title{
The Impact of Oxytocin on Neurite Outgrowth and Synaptic Proteins in Magel2 -Deficient Mice
}

Alexandra Reichova, Fabienne Schaller, Stanislava Bukatova, Zuzana Bacova, Françoise Muscatelli, Jan Bakos

\section{- To cite this version:}

Alexandra Reichova, Fabienne Schaller, Stanislava Bukatova, Zuzana Bacova, Françoise Muscatelli, et al.. The Impact of Oxytocin on Neurite Outgrowth and Synaptic Proteins in Magel2 -Deficient Mice. Developmental Biology, 2021, 10.1002/dneu.22815 . hal-03091758

\section{HAL Id: hal-03091758 https://hal.science/hal-03091758}

Submitted on 4 Jan 2021

HAL is a multi-disciplinary open access archive for the deposit and dissemination of scientific research documents, whether they are published or not. The documents may come from teaching and research institutions in France or abroad, or from public or private research centers.
L'archive ouverte pluridisciplinaire HAL, est destinée au dépôt et à la diffusion de documents scientifiques de niveau recherche, publiés ou non, émanant des établissements d'enseignement et de recherche français ou étrangers, des laboratoires publics ou privés. 


\section{The Impact of Oxytocin on Neurite Outgrowth and Synaptic Proteins in Magel2- Deficient Mice}

Alexandra Reichova ${ }^{1}$, Fabienne Schaller ${ }^{2}$, Stanislava Bukatova ${ }^{1}$, Zuzana Bacova ${ }^{1}$, Françoise Muscatelli ${ }^{2}$, Jan Bakos ${ }^{1,3}$

${ }^{1}$ Institute of Experimental Endocrinology, Biomedical Research Center, Slovak Academy of Sciences, Bratislava, Slovakia

${ }^{2}$ Mediterranean Institute of Neurobiology (INMED), INSERM U901, Parc Scientifique de Luminy, BP 13, 13273 Marseille Cedex 09, France

${ }^{3}$ Institute of Physiology, Faculty of Medicine, Comenius University, Bratislava, Slovakia

Running title: Magel2 deficiency alters synaptic proteins

Key words: Magel2, development, autism, oxytocin, synaptic proteins

Corresponding author:

Jan Bakos, PhD.

Institute of Experimental Endocrinology

Biomedical Research Center, Slovak Academy of Sciences

Dubravska cesta 9, 845 05, Bratislava, Slovakia

Tel. +421-2-3229 5232

Email: j.bakos@savba.sk 


\begin{abstract}
Oxytocin contributes to the regulation of cytoskeletal and synaptic proteins and could therefore affect the mechanisms of neurodevelopmental disorders, including autism. Both the Prader-Willi syndrome and Schaaf-Yang syndrome exhibit autistic symptoms involving the MAGEL2 gene. Magel2-deficient mice show a deficit in social behavior that is rescued following postnatal administration of oxytocin. Here, in Magel2-deficient mice, we showed that the neurite outgrowth of primary cultures of immature hippocampal neurons is reduced. Treatment with oxytocin, but not retinoic acid, reversed this abnormality. In the hippocampus of Magel2-deficient pups, we further demonstrated that several transcripts of neurite outgrowth-associated proteins, synaptic vesicle proteins, and cell-adhesion molecules are decreased. In the juvenile stage, when neurons are mature, normalization or even overexpression of most of these markers was observed, suggesting a delay in the neuronal maturation of Magel2-deficient pups. Moreover, we found reduced transcripts of the excitatory postsynaptic marker, $P s d 95$ in the hippocampus and we observed a decrease of PSD95/VGLUT2 colocalization in the hippocampal CA1 and CA3 regions in Magel2deficient mice, indicating a defect in glutamatergic synapses. Postnatal administration of oxytocin upregulated postsynaptic transcripts in pups; however, it did not restore the level of markers of glutamatergic synapses in Magel2-deficient mice. Overall, Magel2 deficiency leads to abnormal neurite outgrowth and reduced glutamatergic synapses during development, suggesting abnormal neuronal maturation. Oxytocin stimulates the expression of numerous genes involved in neurite outgrowth and synapse formation in early development stages. Postnatal oxytocin administration has a strong effect in development that should be considered for certain neuropsychiatric conditions in infancy.
\end{abstract}




\section{Introduction}

Recent studies have shown that multiple components of the neuronal cytoskeleton, including microtubule-associated proteins, cell-adhesion molecules, and small GTPases participate in the regulation of neurite outgrowth and synapse formation (Zeidán-Chuliá et al., 2013; Hart \& Hobert, 2018; Cao, Deng \& Pocock 2019; Ruhl et al., 2019). Abnormalities in neuritogenesis, elongation of axons and dendrites along with alterations in the expression of synapseassociated and microtubule-associated proteins might contribute to the structural basis of autism pathology (Bakos et al., 2015; Zatkova et al., 2016; Gilbert \& Man, 2017).

Oxytocin (OT) plays a pleiotropic role from birth at the cellular level via binding to G-protein coupled receptors and triggering different signaling pathways (Busnelli \& Chini, 2018; Jurek \& Neumann, 2018). Oxytocin receptors (OXTR) are expressed in the hippocampal excitatory pyramidal neurons and inhibitory interneurons; both are known to be involved in the regulation of social behavior (Lin et al., 2017; Raam et al., 2017; Meira et al., 2018; Young \& Song, 2020). Moreover, it has been suggested that OT controls the development of hippocampal excitatory neurons (Ripamonti et al., 2017). We have recently shown that neuritogenesis is under the control of OXTR (Lestanova et al., 2016; Zatkova et al., 2018). Furthermore, activation of the OXTRs modulates the expression of synaptic adhesion molecules in neuronal cell cultures (Zatkova et al., 2019). It is likely that OT could be involved in the processes of neurite outgrowth and related signaling cascades, however, the downstream effectors are poorly understood. Alterations in OT and its receptors have been shown to cause autism spectrum disorder (ASD)-like phenotypes in rodent models with deficiencies in social function (Sebat et al., 2007; Muscatelli et al., 2018), and thus any alteration in neurite outgrowth may participate in these pathophysiological mechanisms.

The Prader-Willi Syndrome (PWS) and the closely-related Schaaf-Yang Syndrome (SYS) are complex genetic syndromes, which manifest various autistic symptoms. ASD symptoms are more frequent in SYS patients (approx. 80\%) who present point mutations in MAGEL2 only, as compared to PWS (approx. $30 \%$ ) patients, who have a large chromosomal deletion including MAGEL2 (Schaaf et al., 2013; Urreizti et al., 2017). To date, two mouse models deficient for Magel2 have been established (Kozlov et al., 2007; Schaller et al., 2010) and show an impairment of social behavior and cognition at adulthood (Meziane et al., 2015; Fountain et al., 2017). In one of these models, the neonatal treatment of Magel2 ${ }^{\text {tm1.1Mus }}$ mice with OT has been sufficient for the prevention of social and learning deficits in adulthood, in particular social memory (Schaller et al., 2010; Meziane et al., 2015, Bertoni et al., 2020). 
More specifically, in Magel2-deficient mice, we revealed cellular, physiological and biochemical alterations of hippocampal regions, which are known to be associated with social memory engrams involving the OT- system; those alterations are corrected following perinatal administration of OT (Bertoni et al., 2020).

In the present study, we hypothesize that 1) neurite outgrowth is altered in primary cultures of immature hippocampal neurons isolated from Magel2 ${ }^{\text {tml.IMus }}$ (hereafter named Magel2 ${ }^{-/}$) deficient pups, 2) Magel2 deficiency impairs the regulation of hippocampal neurite outgrowth-associated and synaptic transcripts in early postnatal development and 3) OT treatment could restore normal neurite outgrowth and synaptic formation in the early development of Magel2-deficient mice. In addition to the neuronal primary cultures, we also investigated two postnatal critical developmental stages: infancy (P5) and juvenile (P30), which are associated with non-matured (P5) or matured (P30) hippocampal neurons. 


\section{Material and Methods}

\section{Animals}

Mice were handled and cared for in accordance with the Guide for the Care and Use of Laboratory Animals (N.R.C., 1996) and the European Communities Council Directive of September 22nd, 2010 (2010/63/EU, 74). Experimental protocols were approved by the institutional Ethical Committee guidelines for animal research with the accreditation no. B13055-19 from the French Ministry of Agriculture. We maintained grouped-house mice (3-5 mice/cage). All efforts were made to minimize the number of animals used. To overcome the heterogeneity in the analysis of the heterozygous ${ }^{+\mathrm{m} / \mathrm{p}}$ Magel2 $^{\text {tml.1Mus }}$ mice (due to the stochastic expression of the maternal allele of Magel2 when the paternal allele is deleted (Matarazzo \& Muscatelli, 2013), we used here Magel2 ${ }^{\text {tml.1Mus }}$ homozygous $^{-{ }^{--}}$mice, (hereafter named Magel2 $^{-/}$deficient mice) generated as previously described (Schaller et al., 2010). Mice colonies were maintained in the C57BL/6J background. Due to the parental imprinting of Magel2 (paternally expressed only), in order to obtain heterozygote mice $(+\mathrm{m} / \mathrm{p})$, males carrying the mutation on the maternal allele $(-\mathrm{m} /+\mathrm{p})$ were crossed with wild-type $\mathrm{C} 57 \mathrm{BL} / 6 \mathrm{~J}$ females. To obtain homozygote mice (-m/-p), Magel2-deficient homozygote males and females were crossed. It is also important to note that Magel2 $^{-/-}$mothers were observed as having similar maternal behavior as the wild-type (WT). All mice were genotyped by PCR stemming from DNA extracted from tail snips (around $3 \mathrm{~mm}$ ) and using the primers shown in Table 1.

\section{Preparation of Primary Hippocampal Neurons}

Brains from WT ( $\mathrm{n}=15$ pups/morphological analysis, $\mathrm{n}=9$ pups/quantification of excitatory synaptic proteins) or Magel2 $^{-/}$mice ( $\mathrm{n}=7$ pups/morphological analysis, $\mathrm{n}=9$ pups/ quantification of excitatory synaptic proteins) at postnatal day 0 (P0) were dissected on icecold Hank's Balanced Salt Solution - HBSS (Gibco, USA), supplemented with 1\% Antibiotic-Antimycotic (Gibco, USA) and 0.3 M HEPES (Gibco, USA) under a stereomicroscope in order to collect hippocampi. The hippocampal tissues were dissociated for $20 \mathrm{~min}$ at $37^{\circ} \mathrm{C}$ with an enzymatic solution (HBSS, $0.1 \%$ Trypsin, $0.1 \mathrm{mg} / \mathrm{ml}$ DNAse I). Cells were resuspended and plated on 24 -well plates containing cover slips coated with 10 $\mu \mathrm{g} / \mathrm{ml}$ poly-D-lysine (Sigma-Aldrich, Germany) at a density of $0.8 \times 10^{5} / \mathrm{ml}$ in RPMI medium (Sigma-Aldrich, Germany) containing 10\% fetal bovine serum. After $3 \mathrm{~h}$ of cell plating in a $37^{\circ} \mathrm{C}$ and $5 \% \mathrm{CO}_{2}$ incubator, the medium was replaced with a selective growing medium: 
Neurobasal A (Gibco, USA), 1\% Antibiotic-Antimycotic (Gibco, USA), 1\% Glutamax (Gibco, USA) and 2\% supplement B27 (Invitrogen, USA); day in vitro 1 (DIV1). After 5 days in vitro, $50 \%$ of growing media were exchanged. For the purpose of the evaluation of neurite outgrowth and quantification of excitatory synaptic proteins in immature neurons, $1 \mu \mathrm{M}$ OT (Bachem, Switzerland) or $10 \mu \mathrm{M}$ all-trans retinoic acid -ATRA (Sigma-Aldrich, Germany) were added to the medium at DIV7 and DIV8 (48h treatment).

\section{Immunocytochemistry}

After $48 \mathrm{~h}$ incubation (DIV9), the medium was removed and primary hippocampal cells were fixed with 4\% AntigenFix (Diapath, Italy), $\mathrm{pH} 7.4$ for $20 \mathrm{~min}$ at room temperature (RT). The coverslips were washed 2 times with cold PBS and blocked in 3\% (v/v) normal goat serum (NGS) / donkey serum (DS) and 0.1\% Triton X-100 for $30 \mathrm{~min}$ at RT. Cells were stained with primary antibodies diluted in PBS with 3\% serum, 0.1\% Triton X-100 (Table 2) during 2h at RT. Afterwards, the coverslips were rinsed 3 times with cold PBS and incubated with corresponding fluorescent secondary antibodies diluted in PBS (Table 3 ) for $1 \mathrm{~h}$ at RT. The nuclei were stained with 300 nM DAPI (4',6-diamidino-2-phenylindole; Thermo Fisher Scientific, Slovakia) for $1 \mathrm{~min}$. Coverslips were mounted on glass slides with Fluoromount-G (Sigma-Aldrich, Germany).

\section{A) Morphological Analysis}

MAP2 (Microtubule Associated Protein 2) positive cells were considered neurons. Image capturing was performed using an Apotome2 microscope (Zeiss, Germany) at high magnification (20x objective, numerical aperture 0.8). Six coverslips per experimental group and at least 7 areas of interest per coverslip were evaluated by Fiji/ImageJ software. Arborization of dendritic trees was assessed by Sholl analysis plugin (Cloarec et al., 2019). Calculation of the number of intersecting dendrites with concentric circles in the interval from the soma up to $200 \mu \mathrm{m}$ was performed. The length of the longest neurite was quantified from the edge of the nucleus to the apical end of the neurite by three independent members of the research team by manual tracing.

\section{B) Quantification of excitatory synaptic proteins}

For the analysis of excitatory synaptic proteins in primary hippocampal neurons, triple staining for the Postsynaptic Density Protein 95 (PSD95), Vesicular Glutamate Transporter 2 (VGLUT2) and MAP2 were performed. For image acquisition, a Nikon confocal microscope 
(Nikon ECLIPSE Ti-E, A1R+; Netherlands) was used at high magnification (40x objective, numerical aperture 1.3; resolution $1024 \times 1024$ pixels), and image analysis was carried out by Fiji/ImageJ software. Each experimental group consisted of 5 coverslips where at least 10 cells per coverslip were analyzed. Three individual dendritic segments (10 $\mu \mathrm{m}$ each) per neuron, situated at least $10 \mu \mathrm{m}$ from the nucleus, were randomly chosen by two different researchers. Total fluorescence of PSD95 and VGLUT2 normalized on the MAP2 total fluorescence for the purpose of quantifying the excitatory synaptic proteins was evaluated.

\section{OT Treatment}

Pregnant WT and Magel2 ${ }^{-/}$mice were monitored, and the day of birth was marked as postnatal day $0(\mathrm{P} 0)$. The animals were sexed by anogenital distance and assigned to two neonatal treatment groups. Only the male mice were studied. Either a saline solution $(20 \mu 1)$ or $20 \mu 1$ OT (Bachem, Switzerland) diluted in a saline $(0.1 \mu \mathrm{g} / \mu \mathrm{l})$ were given subcutaneously (s.c.) to the mice on days P2 and P3. The experimental protocol, which was previously used and described by Bakos et al. (2014), as well as a dose of OT was used according to the protocol of Schaller et al. (2010). On day P5, the mice were either 1) sacrificed by decapitation and the brains were quickly removed from the skull with the right/left hippocampi being separated, then deep frozen by liquid nitrogen and stored at $-80^{\circ} \mathrm{C}$ or 2 ) deeply anesthetized by dormitor/zoletil and transcardially perfused with 4\% AntigenFix (Diapath, Italy), $\mathrm{pH}$ 7.4. All brains were removed from the skull and postfixed in the same fixative overnight. After fixation, brain tissue was preserved in PBS with $0.01 \%$ sodium azide.

\section{Quantitative Real-Time PCR}

Total RNA from the right hippocampi ( $\mathrm{n}=6$ /group) was isolated by a phenol-chloroform method using TRI-reagent (MRC, Germany) according to the manufacturer's protocol. The tissues separated from the P5 and P30 mice (WT and Magel2 ${ }^{-/}$) were analyzed. The concentration and purity of RNA was determined by a Nanodrop spectrophotometer (Thermo Fisher Scientific, Slovakia). The reverse transcription was carried out using a High-Capacity cDNA Reverse Transcription Kit (Thermo Fisher Scientific, Slovakia) according to the manufacturer's instructions. Quantitative real-time PCR (qRT-PCR) was performed using Power SYBR ${ }^{\circledR}$ Green PCR Master Mix (Thermo Fisher Scientific, Slovakia) and a QuantStudio 5 thermocycler (Thermo Fisher Scientific, Slovakia). Relative gene expression levels were calculated by using the Livak method (Livak \& Schmittgen, 2001). The $2^{-\Delta \Delta C t}$ 
value of each sample was calculated using glyceraldehyde 3-phosphate dehydrogenase (Gapdh) as a reference control gene (primers sequences in Table 4).

\section{Western Blot Analysis}

The left hippocampi (n=6/group) from P5 and P30 mice (WT and Magel2 ${ }^{-/}$) were homogenized by gently shaking a tissue in a lysis buffer $(100 \mathrm{mM} \mathrm{NaCl}, 10 \mathrm{mM}$ Tris, $1 \mathrm{mM}$ EDTA, $1 \mathrm{mM}$ EGTA, $1 \%$ Triton X-100, 10\% v/v glycerol, $0.1 \%$ sodium dodecyl sulphateSDS) with Protease Inhibitor Coctail (Sigma-Aldrich, Germany) during $2 \mathrm{~h}$ at $4^{\circ} \mathrm{C}$. Proteins were gained by centrifugation at $12000 \mathrm{~g}, 4^{\circ} \mathrm{C}$ for $20 \mathrm{~min}$, and the concentrations were quantified using a BCA kit (Thermo Fisher Scientific, Slovakia) with bovine serum albumin (BSA) as a standard. Total proteins were diluted with ultra-pure water and a sample loading buffer (1: 2 solution; $10 \% \mathrm{w} / \mathrm{v}$ SDS, $0.02 \%$ bromophenol blue, and $25 \%$ glycerol in $0.5 \mathrm{M}$ Tris- $\mathrm{HCl}, \mathrm{pH}$ 6.8) and separated on $10 \%$ (for PSD95 detection) or 12\% (for RhoA, RhoB detection) SDS-PAGE running gels (10 $\mu \mathrm{g}$ protein/lane) with 5\% stacking gels at a constant current of $150 \mathrm{~mA}$ as a running parameter. The proteins were transferred to a low fluorescent polyvinylidene difluoride membrane Immobilon-FL $(0.45 \mu \mathrm{m}$ pore size; Merck-Millipore, Czech Republic) by a Mini Trans-Blot ${ }^{\circledR}$ cell system (Bio-Rad, Slovakia) for $2 \mathrm{~h}$ in wet conditions at $300 \mathrm{~mA}$. After the blocking with 4\% w/v BSA (Sigma-Aldrich, Germany) for 1 $\mathrm{h}$ at RT, membranes were incubated overnight at $+4^{\circ} \mathrm{C}$ with primary antibodies (Table 2). The GAPDH protein (Table 2) was used as a reference. Blots were washed three times for $10 \mathrm{~min}$ in Tris Buffered Saline solution with Tween ${ }^{\circledR}$ and then treated with corresponding fluorescent secondary antibodies (Table 3) for 1h at RT. The Odyssey Infrared Imaging System (LI-COR, USA) was used to detect and quantify fluorescent signals in duplicate for each sample. Odyssey 2.0 analytical software (LI-COR, USA) was used to manually signpost bands of interest and quantify the density of each blot band. Results are presented as a percentage of the control group normalized to GAPDH, reference protein.

\section{Immunohistochemistry}

For determination of excitatory synapses in the anterior dorsal CA1 and CA3 hippocampal regions in P5 WT and Magel2 ${ }^{-/}$mice, we investigated the presence of PSD95 and VGLUT2 during OT treatment ( $\mathrm{n}=4$ animals/group). After the perfusion with $4 \%$ AntigenFix (Diapath, Italy), brains were stored overnight in the same fixative and then sectioned on a $7000 \mathrm{smz}-2$ Vibrotome (Campden Instruments LTD, UK) at a thickness of $50 \mu \mathrm{m}$. Sections were temporarily stored $\left(4^{\circ} \mathrm{C}\right)$ in 24 well plates in $\mathrm{PBS}+0.01 \%$ sodium azide. For 
immunohistochemistry, free-floating sections were blocked with 3\% donkey serum (DS), $2 \%$ BSA, $0.01 \%$ Triton X-100 in PBS. After $1 \mathrm{~h}(\mathrm{RT})$, sections were incubated with a combination of primary antibodies: anti-PSD95 and anti-VGLUT2 (Table 2) in 1\% DS, 1\% BSA, $0.4 \%$ Triton X-100 diluted in PBS overnight at $4^{\circ} \mathrm{C}$. After washing with cold PBS (5 $\mathrm{min} / 3$ times), sections were incubated with corresponding secondary antibodies (Table 3) diluted in PBS for $1.5 \mathrm{~h}$ at room temperature. Subsequent sections were rinsed with PBS (5 min / 3times), and $300 \mathrm{nM}$ DAPI was added to stain the nuclei. After final PBS washing, sections were mounted on glass slides with Fluoromount-G (Sigma-Aldrich, Germany). PSD95- and VGLUT2-stained sections were imaged by a Nikon confocal microscope (Nikon ECLIPSE Ti-E, A1R+; Netherlands). Free-floating sections (50 $\mu \mathrm{m}$ thick) were imaged at high magnification (40x objective, numerical aperture 1.3; resolution $1024 \times 1024$ pixels) at $0.5 \mu \mathrm{m}$ steps. Quantification of colocalization between VGLUT2 and PSD95 was performed using the Fiji/ImageJ plugin ComDet v0.4.1 (Bottermann et al., 2019). In brief, particles were detected from three different areas of interest in each part of the hippocampus (CA1, CA3) in both 555 and 647 channels independently with an approximate size of 2 pixels and intensity threshold of $3 \mathrm{SD}$. Colocalization was determined based on the maximum distance of 1 pixel between particles.

\section{Statistical Analysis}

Statistical comparisons of relative gene expression and protein levels were performed using Student's t-test. One-way ANOVA or two-way ANOVA for genotype factors and OT treatment was used when required. As a post hoc, the Bonferroni test or Tukey Kramer for unequal sample sizes were used. Results are expressed as the mean \pm SEM. The value of $p<$ 0.05 was considered statistically significant.

\section{Results}

\section{Neurite outgrowth is impaired in Magel2 $^{-/-}$hippocampal cultures and compensated by OT; however, not by ATRA treatment}

The morphology of neurons of hippocampal primary cultures isolated from Magel $^{-/}$or WT neonates (the day of birth, P0) was evaluated. After dissection, the hippocampal primary cultures were cultivated for 7 days in a growing medium for the purpose of measurement of the longest neurites in immature neurons. At DIV7, cultures were treated either with or without OT $(1 \mu \mathrm{M})$ or ATRA $(10 \mu \mathrm{M})$ for 48 hours. Exposure of primary neurons to the positive control, ATRA, was used to examine neurite outgrowth. Statistical analysis of 
average neurite lengths (Figure 1) by ANOVA revealed significant differences between groups $(\mathrm{p}<0.0001)$. Firstly, we compared the neurite lengths between the control, untreated WT, and Magel2 ${ }^{-/}$neurons (Figure 1a), and observed a significant $15 \%$ decrease $(\mathrm{p}<0.001)$ in length of neurites $(102.6 \pm 3.12 \mu \mathrm{m})$ in the Magel2 $^{-/}$neurons compared to the WT $(120.9 \pm 3.37 \mu \mathrm{m})$. Afterwards, we examined the effects of OT or ATRA treatment in both genotypes (Figure 1a). In WT neurons, the average length of neurites significantly increased by $10 \%$ in response to OT $(132.9 \pm 3.13 \mu \mathrm{m} ; \mathrm{p}<0.05)$ and by $30 \%$ in response to ATRA $(157.5 \pm 4.02 \mu \mathrm{m} ; \mathrm{p}<0.001)$ incubation when compared to untreated WT neurons $(120.9 \pm 3.37$ $\mu \mathrm{m})$. In the Magel2 $^{-/}$neurons, we also observed a similar $13 \%$ increase of neurite outgrowth in the presence of OT $(137.2 \pm 3.32 \mu \mathrm{m} ; \mathrm{p}<0.01)$; however, application of ATRA did not induce elongation of neurites $(109.6 \pm 2.68 \mu \mathrm{m})$. We also analyzed the number of neurons with the longest neurite expressed as a percentage of the total measured neurons. Based on the length of the neurites, we divided the neurons into 4 categories for each experimental group (Figure 1b). We found a lower percentage of neurons with the longest neurite over $150 \mu \mathrm{m}$ in the Magel2 $^{-/}$neurons (16.1\%) when compared to the WT neurons $(24.8 \%)$. The application of ATRA increased the number of neurons with the longest neurite in the WT neurons $(55.5 \%)$; however, no effects were observed in the Magel2 $^{-/}$neurons. Similarly, OT treatment increased the number of neurons with the longest neurite in the WT $(35.3 \%)$ and Magel2 ${ }^{-/}$ neurons (39\%). The opposite effect of the Magel2 deficiency was observed when neurites with a length up to $50 \mu \mathrm{m}$ were evaluated. The percentage of cells with neurites up to $50 \mu \mathrm{m}$ long was higher in the Magel2 ${ }^{-/}$neurons (14.4\%) compared to the WT neurons $(6.2 \%)$. By using Sholl analysis, we were able to get a detailed look at the neurite length and number of neurite branches in the neurons in a visual field (Figure 2a). We found a $27 \%$ higher sum of intersections up to $30 \mu \mathrm{m}$ away from the nucleus in Magel2 $^{-/}(139.58 \pm 7.23)$ in comparison to the WT neurons $(109.75 \pm 5.05)$. Overall, in these primary cell cultures, we observed a decrease in neurite outgrowth in Magel2-deficient mice versus WT mice. OT treated cell cultures increased neurite outgrowth and normalized the neurite length in Magel2 $^{-/}$neurons similarly to the effect observed in WT. However, it was unexpected that ATRA treatment would have no effect on the neurite growth of Magel2 ${ }^{-/}$neurons, suggesting that the lack of Magel2 prevents the action of ATRA.

\section{The quantity of neurite outgrowth-associated transcripts is altered during development of the hippocampus in Magel2 $^{-/}$mice compared with WT controls}


In order to further study the deficit in neurite outgrowth in Magel2 $^{-/-}$mice versus the WT genotype, we looked at differences in mRNA transcripts or protein levels of specific neurite outgrowth associated proteins (Figure 3) at two different developmental stages: in five dayold pups (P5) and in 30 day-old mice (P30) in the hippocampal tissue. We observed several changes in Magel2-deficient mice. Indeed, at P5, the mRNA levels of Growth associated protein 43-Gap43 (0.73 $\pm 0.09 ; \mathrm{p}<0.001)$ and p21 activated kinase 1 - Pak1 $(0.74 \pm 0.12 ; \mathrm{p}<$ 0.01 ) were significantly reduced compared to the WT mice (Figure 3a). The quantity of Map2 transcripts was not different, however, between genotypes. Furthermore, we quantified expression of Ras-related C3 botulinum toxin substrate - Racl, chosen for its highlyrecognized roles within Rho GTPase signaling, which is important in regulating the cytoskeleton involved in axonal outgrowth (Cao, Deng \& Pocock 2019). Because ATRA did not have any effect on neurite outgrowth in Magel2-deficient mice, we also evaluated GTPdependent upstream kinase T-cell lymphoma invasion and metastasis 1 - Tiam1 and downstream kinase LIM domain kinase 1 - Limk1, both enzymes associated with rearranging of the cytoskeleton and interact with the retinoid receptor function (Ishaq et al., 2011). At P5, no difference in Racl expression was found; however, we observed lower mRNA levels of Tiaml $(0.43 \pm 0.10 ; \mathrm{p}<0.001)$ and Limk1 $(0.82 \pm 0.10 ; \mathrm{p}<0.05)$ compared to the WT (Figure 3b). Tiam1 and Limk1 are involved in signaling cascades under the control of small Rho GTPases and the Ras homolog family members A and B (RhoA and RhoB) as well. We then studied the RhoA and RhoB transcripts and proteins in Magel2 $^{-/}$mice (Figure 4). At P5, expression of $R h o B$ increased at the transcript $(1.60 \pm 0.19 ; \mathrm{p}<0.01)$ and protein $(171.20 \pm 25.89 ; \mathrm{p}<0.05)$ level compared to the WT; however, such changes were not observed for the expression of RhoA (Figure 4a, 4b).

At P30, the same significant level of reduction for Gap43 $(0.75 \pm 0.10 ; \mathrm{p}<0.01)$ and for Pak1 $(0.59 \pm 0.07 ; \mathrm{p}<0.01)$ was observed along with lower mRNA levels $(0.67 \pm 0.07 ; \mathrm{p}<0.001)$ of Map2 in Magel2 $^{-/}$mice (Figure 3c); mRNA levels of Racl were also significantly lower $(0.51 \pm 0.09 ; \mathrm{p}<0.01)$ in Magel $2^{-/}$mice when compared to the WT mice. Conversely, Tiam 1 $(1.63 \pm 0.29 ; \mathrm{p}<0.01)$ and Limk1 $(1.27 \pm 0.06 ; \mathrm{p}<0.001)$ gene expression levels increased in Magel2 $^{-/}$mice (Figure 3d). At P30, we observed a significant decrease of the mRNA level of RhoA $(0.81 \pm 0.08 ; \mathrm{p}<0.05)$ in Magel2-deficient mice and a similar trend towards a decrease in the protein levels of RHOA $\left(77.87 \pm 9.43\right.$; ns) in Magel $^{-/}$mice was found; RhoB was expressed at the same level in both genotypes (Figure 4e, 4f). In conclusion, in P5 immature neurons, we observed a significant reduction in the quantity of several transcripts for factors 
involved in neurite outgrowth in Magel2 $2^{-/}$mice. At P30, in mature neurons, most of the reduced markers observed at P5 had a normal or even higher level of expression.

The quantity of presynaptic transcripts is reduced at P5 and normalized or increased at P30 in Magel2 $^{-/}$mice compared to the WT mice

The synapse-associated molecules (Figure 5) were also examined. At days P5 and P30, we investigated two splicing variants of cell-adhesion molecules, neurexins (Nrxns), and two synaptic vesicle proteins: Synapsin I and Synaptophysin; all of which are known to be present in the "presynaptic compartments". At P5, the quantity of Nrxn1 $\alpha$ and Nrxn $2 \beta$ transcripts was significantly lower $(0.87 \pm 0.05 ; \mathrm{p}<0.05$ and $0.67 \pm 0.13 ; \mathrm{p}<0.01$, respectively) in Magel2deficient mice compared to the WT mice. No change was observed for mRNA levels of Nrxn $1 \beta$ and Nrxn2 $\alpha$ (Figure 5a). We also observed a decrease of Synapsin I $(0.86 \pm 0.05 ; \mathrm{p}<$ $0.05)$ and Synaptophysin $(0.87 \pm 0.09 ; \mathrm{p}<0.05)$ transcripts in Magel2 ${ }^{-/-}$mice (Figure 5b). At P30, we found that in Magel2 ${ }^{-/}$mice, the quantity of Nrxn1 $\beta(1.16 \pm 0.02 ; \mathrm{p}<0.05)$, Nrxn $2 \alpha$ $(1.19 \pm 0.07 ; \mathrm{p}<0.001)$ and $\operatorname{Nrxn} 2 \beta(1.23 \pm 0.09 ; \mathrm{p}<0.01)$ transcripts was significantly higher compared to the WT mice (Figure 5c). No differences were found in mRNA expression of Synapsin I and Synaptophysin at P30 (Figure 5d). Altogether, these data suggest a significant decrease in the quantity of presynaptic markers at P5 in Magel2-deficient mice compared to the WT mice; this deficit appears normalized at P30 with even a slight increase.

\section{Shank and Neuroligin postsynaptic transcripts are increased in $\mathrm{Magel}^{-/}$mice compared to the WT mice at P30 but not at P5}

Additionally, we also examined whether Magel2 deficiency plays a role in the regulation of postsynaptic transcripts and proteins in the hippocampal tissue (Figure 6). We measured levels of scaffolding and cell-adhesion molecules involved in the balance between excitatory and inhibitory synapses (Prange et al., 2004; Varoqueaux et al., 2006). At P5, no differences were found in transcripts of "SH3 and multiple ankyrin repeat domains" (Shank1-3) and Neuroligins (Nlgn1-2) genes in Magel2 ${ }^{-/}$mice compared to the WT mice (Figure 6a, 6b). Nlgn3 transcript was the only slightly increased postsynaptic gene in Magel2 ${ }^{-/}$mice at P5 $(1.15 \pm 0.13 ; \mathrm{p}<0.05)$ (Figure $6 \mathrm{~b})$. In contrast to early development, several cases of genes coding for postsynaptic transcripts were upregulated at P30 (Figure 6c, 6d). Indeed, we found

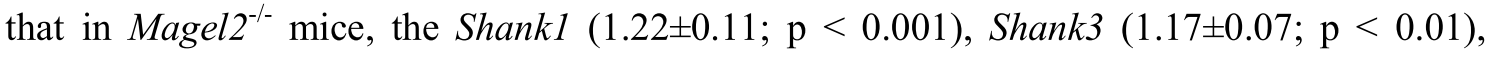
$N \operatorname{lgn} 2(1.37 \pm 0.07 ; \mathrm{p}<0.001)$ and $N \operatorname{lgn} 3(1.17 \pm 0.10 ; \mathrm{p}<0.05)$ transcripts were significantly higher compared to the WT mice. Conversely, Nlgn1 transcript was decreased $(0.82 \pm 0.05 ; \mathrm{p}<$ 
0.01) in Magel2 $2^{--}$mice compared to the WT mice. The expression of Postsynaptic density protein 95 (Psd95) was also regulated differently in P5 and P30 (Figure 7). We found significantly lower $(0.77 \pm 0.05 ; \mathrm{p}<0.001)$ gene expression and the same trend for the protein levels of PSD95 (85.55 \pm 15.47 ; ns) in P5 Magel2-deficient mice (Figure 7a, 7b). However, the trend for Psd95 changes at P30 was the opposite. Statistical analysis revealed no change in gene expression, but significantly higher $(138.90 \pm 15.95 ; \mathrm{p}<0.05)$ protein levels of PSD95 at P30 (Figure 7e). In conclusion, at P5, a quantity of postsynaptic transcripts and proteins revealed no change globally, yet only a small increase of Nlgn3 and decrease of PSD95. At P30, we found an increase of Shank and Nlgn transcripts, but a decrease of Nlgnl transcript in Magel $^{-/}$mice compared to the WT mice and an increase of PSD95.

OT stimulates the expression of presynaptic and postsynaptic transcripts in P5 $\mathrm{Magel2}^{-/}$ mice compared to the WT mice

We also investigated the effect of OT treatment ( $2 \mu \mathrm{g} /$ pup, s.c.) administered at P2 and P3 on the levels of presynaptic and postsynaptic transcripts (values and statistics are shown in Table 5). At P5, following OT treatment, we observed significantly higher levels of Nrxn1 $\beta$ ( $\mathrm{p}<$ $0.001)$, Nrxn2 $\alpha(\mathrm{p}<0.01)$, Nlgn1 $(\mathrm{p}<0.01)$ and Nlgn2 $(\mathrm{p}<0.001)$ transcripts in Magel2deficient mice compared to the WT mice. The quantity of those transcripts was unchanged in Magel $^{-/-}$mice compared with the WT mice. Furthermore, we observed a significant decrease in the quantity of Psd95 ( $\mathrm{p}<0.001)$, Nrxn1 $\alpha(\mathrm{p}<0.05)$ and Nrxn2 $\beta(\mathrm{p}<0.01)$ in Magel2deficient mice compared with the WT mice (Table 5), and OT treatment normalized the quantity of those transcripts. Globally, OT treatment enhanced the expression of all the previous studied transcripts at P5 in Magel2-deficient mice except for Nlgn3.

\section{A lower immunofluorescence signal of excitatory presynaptic VGLUT2 and postsynaptic PSD95 markers in Magel2 $^{-/}$compared to WT primary hippocampal neurons}

For the analysis of excitatory synaptic proteins in primary hippocampal neurons, triple staining for PSD95, VGLUT2, and MAP2 was performed using specific antibodies. The total quantity of fluorescence of the VGLUT2 normalized on MAP2 (VGLUT2/MAP2; Figure 8a) decreased by $21 \%$ in primary hippocampal neurons isolated from the Magel2 ${ }^{-/}(3.06 \pm 0.11 ; \mathrm{p}$ $<0.01)$ mice compared to the WT $(3.87 \pm 0.29)$ mice. Similarly, the signal intensity of PSD95/MAP2 significantly decreased by $37 \%$ in Magel2 $^{-/}(0.86 \pm 0.02 ; \mathrm{p}<0.001)$ compared 
with WT (1.37 \pm 0.08$)$ neurons (Figure $8 \mathrm{~b}$ ). These results suggest a decrease of markers of glutamatergic synapses in Magel2 $^{-/}$hippocampal cultures compared with the WT.

\section{At P5, Magel2 $^{-/}$mice manifest a lower immunofluorescence signal for PSD95/VGLUT2} colocalization in the hippocampal CA1 and CA3 regions compared with the WT mice, and OT treatment decreases the signal in WT mice

In order to gain more insight into the excitatory synaptic connections in the hippocampus, we quantified the anterior dorsal areas of CA1 and CA3 regions for the PSD95/VGLUT2 colocalization in the tissue isolated from P5 mice (Figure 9). A significant $44 \%$ decrease of the colocalization in the hippocampal area CA1 in Magel2 ${ }^{-/}(27.68 \pm 4.64 ; \mathrm{p}<0.05)$ mice compared to the WT $(49.36 \pm 6.69)$ mice was found (Figure 9a). Surprisingly, OT treatment decreased the quantity of colocalized signal by $61 \%$ in the hippocampal area CA1 in WT mice $(19.21 \pm 2.57 ; \mathrm{p}<0.001)$ without any additional effect in Magel2-deficient mice $(28.19 \pm 4.12$;

$\mathrm{p}<0.05$ ). A significant $29 \%$ decrease in the colocalization of PSD95/VGLUT2 in the hippocampal area CA3 in Magel2-deficient mice $(68.99 \pm 7.45 ; \mathrm{p}<0.05)$ compared to the WT mice (97.55 \pm 7.31 ) was found (Figure 9b). Administration of OT decreased the quantity of the colocalized signal by $32 \%$ in the WT mice only $(66.30 \pm 4.85 ; \mathrm{p}<0.05)$. Therefore, we confirmed a decrease in markers of glutamatergic synapses in brain tissue in the CA1 and CA3 hippocampal regions of Magel2 ${ }^{-/}$at P5 that is not rescued after OT treatment at P2-P3. Unexpectedly, we observed a strong and significant reduction of markers of glutamatergic synapses in WT pups treated with OT.

The quantity of glutamic acid decarboxylase transcripts and proteins are increased in the hippocampus of $\mathrm{Magel2}^{-/-}$mice compared to the WT mice.

In order to achieve a global view of the GABAergic activity, we investigated the quantity of two isoforms of glutamic acid decarboxylase (GAD65 and GAD67), the enzyme that catalyzes the formation of $\gamma$-aminobutyric acid (GABA) from glutamic acid at both developmental stages. GAD67 is constitutively active and produces more than $90 \%$ of GABA; GAD65 is transiently activated and augments GABA levels for rapid modulation of inhibitory transmission. Thus, we examined whether inhibitory transmission is affected in Magel $^{-/}$mice. At P5 (Figure 10a and 10b), we found a significant increase of Gad65 $(1.38 \pm 0.05 ; \mathrm{p}<0.01)$ and Gad67 $(1.53 \pm 0.24 ; \mathrm{p}<0.001)$ transcripts and a non-significant trend for the GAD65+GAD67 protein levels (132.54 \pm 16.00 ; ns) in Magel2-deficient mice. At P30 (Figure 10d and 10e), we continued to observe a significant increase of Gad65 (1.40 \pm 0.21 ; p 
$<0.01)$, Gad67 (1.63 $\pm 0.34 ; \mathrm{p}<0.01)$ transcripts, and the protein levels of GAD 65+GAD67 $(142.31 \pm 19.15 ; \mathrm{p}<0.05)$. These results show an increase of expression of Gad65 and Gad67 at P5, which is more significant at P30 in Magel2 $^{-/}$mice, suggesting a higher number of GABAergic neurons or an increase of GABA production and GABA activity in Magel2deficient mice. 


\section{Discussion}

Impaired neurite outgrowth in immature hippocampal neurons is accompanied by alteration in the retinoic acid signaling pathway in Magel2-deficient mice

Here, we showed impaired neurite outgrowth and dendritic arborization in primary cultures of immature hippocampal neurons isolated from Magel2 $^{-/}$mice. Our data observed in hippocampal neurons are consistent with abnormal development of the hypothalamic neural projections at P8 Magel2-deficient mice found in the previous study by Maillard et al. (2016). Furthermore, the authors observed the role of Magel2 in axonal growth by quantification of neurites in N2a cells transfected with Magel2. Moreover, a recent study has demonstrated impaired dendrite formation in induced pluripotent stem cell (iPSC)-derived neurons from Schaaf-Yang syndrome suffering patients (Crutcher et al., 2019). Interestingly, we found that ATRA failed to induce neurite extension in neurons isolated from $\mathrm{Magel}^{-/-}$mice, although ATRA enhanced neurite outgrowth in the primary neurons of WT mice. ATRA, a naturally occurring retinoid metabolite of vitamin A, is routinely used as a differentiation factor, as well as a positive stimulus for the examination of neurite outgrowth (Clagett-Dame, McNeill \& Muley, 2006; Kovalevich \& Langford, 2013). Our data suggest that the retinoid signaling pathway is altered in Magel2-deficient animals. One possible explanation is offered by interference with the mTORC1 signaling pathway. It has been shown that mTORC1 is upregulated in the brains of Magel2 null mice and accompanied by impairment of dendrite formation (Crutcher et al., 2019). Therefore, insufficient ATRA action on neurite outgrowth in Magel2-deficient mice could be associated with potential downstream alterations in vesicle trafficking, as well as the corresponding increased lipid droplet accumulation and changes in neuronal morphology observed in the study by Crutcher at al. (2019). Interestingly enough, it has been reported that ATRA can stimulate the expression of Mage family genes, including the Magel2 in various cell lines in vitro (Gordeeva, Gordeev \& Khaydukov, 2019), suggesting that Magel2 is downstream of the ATRA pathway. In this study, we observed decreased expression of Limk1 and Tiam1, which are enzymes known to be associated with rearranging of the cytoskeleton (see scheme in figure 11) and interact with the retinoid receptor function (Ishaq et al., 2011). Activation of LIMK1 is associated with retinoic acid-stimulated neurite outgrowth (Arastoo et al., 2016). LIMK1 regulates actin dynamics by phosphorylating cofilin, which contributes to processes of neurite elongation (Reichova et al., 2018). Since neurite elongation is essentially associated with functional intracellular transport processes, it is important to note that Magel2 serves as a ubiquitin ligase enhancer and mediates the 
posttranslational modification of many substrates. One of the relevant issues regarding the impairments of neurite outgrowth is the mechanistic link of Magel2 to the molecular machinery contributing to retrograde transport pathways (Hao et al., 2013).

\section{Hippocampal glutamatergic synaptic markers are decreased in Magel2-deficient mice}

In primary hippocampal neurons, we found that Magel2-deficient mice have a lower amount of the presynaptic excitatory VGLUT2 transporter density. In addition, at day P5, the immunohistochemistry of PSD95/VGLUT2 colocalization showed a lower signal in the hippocampal areas CA1 and CA3 in Magel2-deficient mice. This lower density of the signal indicates that the number of glutamatergic neurons/synapses could be affected at this stage of development. Although glutamatergic synapses during the first postnatal week of development are not yet fully developed (Naskar et al., 2019), glutamatergic activity is necessary for their maturation. With regards to the demonstrated impairment of neurite outgrowth in the hippocampal cells in Magel2-deficient mice, it could be assumed that there is a delay in the maturation of hippocampal circuits. Under normal conditions, there are known synaptic connections between pyramidal neurons and interneurons within and between the areas of CA1 and CA2/CA (Booker \& Vida, 2018). Indeed, in line with those observations, our other recent study has shown that the GABAergic activity was increased, and glutamatergic activity was reduced in the aCA3d pyramidal neurons when using hippocampal acute slices of Magel2-/- juvenile mice (Bertoni et al., 2020). It is assumed that the reduced glutamatergic activity most likely results from a postsynaptic alteration. The development of functional glutamatergic synapses could be delayed in conditions of Magel2 deficiency. Interestingly, we also observed a higher expression of "GAD65+GAD67", which suggests that Magel2 deficiency at both developmental stages P5 and P30 is associated with enhanced GABAergic neurotransmission. In line with that, we previously observed an increase of GABAergic activity in Magel2-deficient hippocampal neurons (Bertoni et al., 2020). Indeed, it appears that Magel2 deficiency is associated with GABAergic and glutamatergic alterations. Our results indicate more profound alterations at P5 compared to P30 Magel2deficient mice, thus suggesting a delay in neuronal and circuitry maturation.

\section{Deficits observed in Magel2-deficient mice are reversed by OT treatment}

We found that OT increased the neurite length in the WT and Magel2 $2^{-/-}$primary hippocampal neurons. This is in line with our previous results on neuronal cell lines treated with OT (Lestanova et al., 2016; Zatkova et al., 2018). Although it has been demonstrated that Magel2- 
deficient neonates suffer from a significant reduction in OT (Schaller et al., 2010), OXTRs could be fully functional, which explains the stimulatory effect of OT on Magel2 $^{-/-}$neurons. Globally, in the hippocampus at P5, we observed an increase of expression of several transcripts involved in neurite outgrowth following an administration of OT (suggesting a stimulatory role of OT in these processes). In addition, we showed that OT administration reduces the quantity of PSD95/VGLUT2 colocalization in the WT mice with no additional effect in Magel2-deficient mice. Thus, we suggest that when neurons are still immature, OT administration reduces the quantity of glutamatergic synapses in the hippocampal regions of WT mice; however, not in Magel2-deficient mice, which had previously presented decreased glutamatergic activity. In line with our results, a recent study showed that OT treatment controls the development of hippocampal glutamatergic neurons (Ripamonti et al., 2017). In the context of pathophysiological conditions present in Magel2-deficient mice, an alteration in OT system might result in abnormal and delayed development of hippocampal circuits. In correspondence to this, another study involving adult Magel2-deficient mice has found reduced excitatory and increased inhibitory currents in OT neurons (Ates et al., 2019). We need to be careful, however, when making any conclusions, since the role of OT could be specifically-related to the developing immature hippocampal neurons and could also depend on the density of OXTRs in specific hippocampal subregions (Raam et al., 2017; Young \& Song, 2020).

\section{Conclusion}

This is the first time that an alteration in the neurite outgrowth of immature hippocampal neurons in Magel2 $^{-/}$mice has been demonstrated to be accompanied by a decrease in the expression of factors associated with neurite growth. We found that OT compensates for the dendritic arborization defects observed in primary Magel2 ${ }^{-/}$hippocampal neurons and stimulates the expression of factors involved in neurite outgrowth overall (see scheme in figure 11). A deficit of glutamatergic synapses has also been shown in Magel2-deficient mice that are not restored after OT administration. Unexpectedly, our results suggest that OT administration in WT mice induces a reduction in the number of glutamatergic synapses, supporting the idea that OT controls the formation of glutamatergic synapses. These results reveal the strong impact of early childhood OT treatment on the development of the nervous system and the interest in certain neuropsychiatric conditions. 


\section{Acknowledgement}

We would like to thank Dr. Karel Frimmel, Centre of Experimental Medicine SAS for his assistance with confocal microscopy, Dr. Igor Medina, INMED, Marseille for critical reading, as well as Michael Sabo for proofreading of the manuscript.

\section{Conflict of interest statement}

The authors have no conflicts of interest to declare.

\section{Funding Sources}

This study was funded by the Grant Agency of Ministry of Education and the Slovak Academy of Sciences (VEGA 2/0038/18, VEGA 2/0155/20), as well as by the Slovak Research and Development Agency project (APVV-15-205, SK-FR-2017-0012 and SK-FR19-0015).

\section{Data availability statement}

The data that support the findings of this study are available from the corresponding author upon reasonable request.

\section{Author Contributions:}

JB, FM, ZB, and AR designed the research. AR, FS and SB performed the research. ZB, AR and JB analyzed the data. AR, FM and JB wrote the paper. 


\section{References}

Arastoo, M., Hacker, C., Popovics, P., Lucocq, J. M., \& Stewart, A. J. (2016). Phospholipase C- $\eta 2$ interacts with nuclear and cytoplasmic LIMK-1 during retinoic acidstimulated neurite growth. Histochemistry and cell biology, 145(2), 163-173. https://doi.org/10.1007/s00418-015-1390-7.

Arsenault, J., Gholizadeh, S., Niibori, Y., Pacey, L. K., Halder, S. K., Koxhioni, E., Konno, A., Hirai, H., \& Hampson, D. R. (2016). FMRP Expression Levels in Mouse Central Nervous System Neurons Determine Behavioral Phenotype. Human gene therapy, 27(12), 982-996. https://doi.org/10.1089/hum.2016.090.

Ates, T., Oncul, M., Dilsiz, P., Topcu, I. C., Civas, C. C., Alp, M. I., Aklan, I., Ates Oz, E., Yavuz, Y., Yilmaz, B., Sayar Atasoy, N., \& Atasoy, D. (2019). Inactivation of Magel2 suppresses oxytocin neurons through synaptic excitation-inhibition imbalance. Neurobiology of disease, 121, 58-64. https://doi.org/10.1016/j.nbd.2018.09.017.

Bakos, J., Bacova, Z., Grant, S. G., Castejon, A. M., \& Ostatnikova, D. (2015). Are Molecules Involved in Neuritogenesis and Axon Guidance Related to Autism Pathogenesis? Neuromolecular medicine, 17(3), 297-304. https://doi.org/10.1007/s12017-015-8357-7.

Bakos, J., Lestanova, Z., Strbak, V., Havranek, T., \& Bacova, Z. (2014). Neonatal manipulation of oxytocin prevents lipopolysaccharide-induced decrease in gene expression of growth factors in two developmental stages of the female rat. Neuropeptides, 48(5), 281-286. https://doi.org/10.1016/j.npep.2014.06.004.

Bertoni, A., Schaller, F, Tyzio, R., Gaillard, S., Santini, F., Xolin, M., Diabira, D., Vaidyanathan, R., Matarazzo, V., Medina. I., Hammock, E., Zhang. J, Chini, B., Gaiarsa, J.L., \& Muscatelli, F. Acute neonatal oxytocin impacts hippocampal network development and restores adult social memory deficits in a mouse model of autism spectrum disorder. bioRxiv, doi: https://doi.org/10.1101/2020.09.21.306217

Booker, S. A., \& Vida, I. (2018). Morphological diversity and connectivity of hippocampal interneurons. Cell and tissue research, 373(3), 619-641. https://doi.org/10.1007/s00441-018$2882-2$.

Bottermann, M., Foss, S., Caddy, S. L., Clift, D., van Tienen, L. M., Vaysburd, M., Cruickshank, J., O'Connell, K., Clark, J., Mayes, K., Higginson, K., Lode, H. E., McAdam, M. B., Sandlie, I., Andersen, J. T., \& James, L. C. (2019). Complement C4 Prevents Viral Infection through Capsid Inactivation. Cell host \& microbe, 25(4), 617-629.e7. https://doi.org/10.1016/j.chom.2019.02.016. 
Bozdagi, O., Sakurai, T., Papapetrou, D., Wang, X., Dickstein, D. L., Takahashi, N., Kajiwara, Y., Yang, M., Katz, A. M., Scattoni, M. L., Harris, M. J., Saxena, R., Silverman, J. L., Crawley, J. N., Zhou, Q., Hof, P. R., \& Buxbaum, J. D. (2010). Haploinsufficiency of the autism-associated Shank3 gene leads to deficits in synaptic function, social interaction, and social communication. Molecular autism, 1(1), 15. https://doi.org/10.1186/2040-2392-1-15.

Busnelli, M., \& Chini, B. (2018). Molecular Basis of Oxytocin Receptor Signalling in the Brain: What We Know and What We Need to Know. Current topics in behavioral neurosciences, 35, 3-29. https://doi.org/10.1007/7854_2017_6.

Cao, W., Deng, S., \& Pocock, R. (2019). The UIG-1/CDC-42 guanine nucleotide exchange factor acts in parallel to CED-10/Rac1 during axon outgrowth in Caenorhabditis elegans. Small GTPases, 1-7. Advance online publication. https://doi.org/10.1080/21541248.2019.1610302.

Clagett-Dame, M., McNeill, E. M., \& Muley, P. D. (2006). Role of all-trans retinoic acid in neurite outgrowth and axonal elongation. Journal of neurobiology, 66(7), 739-756. https://doi.org/10.1002/neu.20241.

Cloarec, R., Riffault, B., Dufour, A., Rabiei, H., Gouty-Colomer, L. A., Dumon, C., Guimond, D., Bonifazi, P., Eftekhari, S., Lozovaya, N., Ferrari, D. C., \& Ben-Ari, Y. (2019). Pyramidal neuron growth and increased hippocampal volume during labor and birth in autism. Science advances, 5(1), eaav0394. https://doi.org/10.1126/sciadv.aav0394.

Crutcher, E., Pal, R., Naini, F., Zhang, P., Laugsch, M., Kim, J., Bajic, A., \& Schaaf, C. P. (2019). mTOR and autophagy pathways are dysregulated in murine and human models of Schaaf-Yang syndrome. Scientific reports, 9(1), 15935. https://doi.org/10.1038/s41598-01952287-2.

Dorval, V., Smith, P. Y., Delay, C., Calvo, E., Planel, E., Zommer, N., Buée, L., \& Hébert, S. S. (2012). Gene network and pathway analysis of mice with conditional ablation of Dicer $\begin{array}{llll}\text { in } & \text { nest-mitotic } & \text { one, } 44060 .\end{array}$ https://doi.org/10.1371/journal.pone.0044060.

Du, Z., Tertrais, M., Courtand, G., Leste-Lasserre, T., Cardoit, L., Masmejean, F., Halgand, C., Cho, Y. H., \& Garret, M. (2017). Differential Alteration in Expression of Striatal $\mathrm{GABA}_{\mathrm{A}} \mathrm{R}$ Subunits in Mouse Models of Huntington's Disease. Frontiers in molecular neuroscience, 10, 198. https://doi.org/10.3389/fnmol.2017.00198.

Fountain, M. D., Tao, H., Chen, C. A., Yin, J., \& Schaaf, C. P. (2017). Magel2 knockout mice manifest altered social phenotypes and a deficit in preference for social novelty. Genes, brain, and behavior, 16(6), 592-600. https://doi.org/10.1111/gbb.12378. 
Gilbert, J., \& Man, H. Y. (2017). Fundamental Elements in Autism: From Neurogenesis and Neurite Growth to Synaptic Plasticity. Frontiers in cellular neuroscience, 11, 359. https://doi.org/10.3389/fncel.2017.00359.

Gordeeva, O., Gordeev, A., \& Khaydukov, S. (2019). Expression dynamics of Mage family genes during self-renewal and differentiation of mouse pluripotent stem and teratocarcinoma cells. $\quad$ Oncotarget, $\quad \mathbf{1 0}(35), \quad 3248-3266$. https://doi.org/10.18632/oncotarget.26933.

Hao, Y. H., Doyle, J. M., Ramanathan, S., Gomez, T. S., Jia, D., Xu, M., Chen, Z. J., Billadeau, D. D., Rosen, M. K., \& Potts, P. R. (2013). Regulation of WASH-dependent actin polymerization and protein trafficking by ubiquitination. Cell, 152(5), 1051-1064. https://doi.org/10.1016/j.cell.2013.01.051.

Hart, M. P., \& Hobert, O. (2018). Neurexin controls plasticity of a mature, sexually dimorphic neuron. Nature, 553(7687), 165-170. https://doi.org/10.1038/nature25192.

Ishaq, M., Lin, B. R., Bosche, M., Zheng, X., Yang, J., Huang, D., Lempicki, R. A., Aguilera-Gutierrez, A., \& Natarajan, V. (2011). LIM kinase 1 - dependent cofilin 1 pathway and actin dynamics mediate nuclear retinoid receptor function in $\mathrm{T}$ lymphocytes. $B M C$ molecular biology, 12, 41. https://doi.org/10.1186/1471-2199-12-41.

Jurek, B., \& Neumann, I. D. (2018). The Oxytocin Receptor: From Intracellular Signaling to Behavior. Physiological reviews, 98(3), 1805-1908. https://doi.org/10.1152/physrev.00031.2017.

Kawanai, T., Ago, Y., Watanabe, R., Inoue, A., Taruta, A., Onaka, Y., Hasebe, S., Hashimoto, H., Matsuda, T., \& Takuma, K. (2016). Prenatal Exposure to Histone Deacetylase Inhibitors Affects Gene Expression of Autism-Related Molecules and Delays Neuronal Maturation. Neurochemical research, 41(10), 2574-2584. https://doi.org/10.1007/s11064016-1969-y.

Kovalevich, J., \& Langford, D. (2013). Considerations for the use of SH-SY5Y neuroblastoma cells in neurobiology. Methods in molecular biology (Clifton, N.J.), 1078, 921. https://doi.org/10.1007/978-1-62703-640-5_2.

Kozlov, S. V., Bogenpohl, J. W., Howell, M. P., Wevrick, R., Panda, S., Hogenesch, J. B., Muglia, L. J., Van Gelder, R. N., Herzog, E. D., \& Stewart, C. L. (2007). The imprinted gene Magel2 regulates normal circadian output. Nature genetics, 39(10), 1266-1272. https://doi.org/10.1038/ng2114. 
Lestanova, Z., Bacova, Z., Kiss, A., Havranek, T., Strbak, V., \& Bakos, J. (2016). Oxytocin Increases Neurite Length and Expression of Cytoskeletal Proteins Associated with Neuronal Growth. Journal of molecular neuroscience: MN, 59(2), 184-192. https://doi.org/10.1007/s12031-015-0664-9.

Lin, Y. T., Hsieh, T. Y., Tsai, T. C., Chen, C. C., Huang, C. C., \& Hsu, K. S. (2018). Conditional Deletion of Hippocampal CA2/CA3a Oxytocin Receptors Impairs the Persistence of Long-Term Social Recognition Memory in Mice. The Journal of neuroscience : the official journal of the Society for Neuroscience, 38(5), 1218-1231. https://doi.org/10.1523/JNEUROSCI.1896-17.2017.

Livak, K. J., \& Schmittgen, T. D. (2001). Analysis of relative gene expression data using real-time quantitative PCR and the 2(-Delta Delta C(T)) Method. Methods (San Diego, Calif.), 25(4), 402-408. https://doi.org/10.1006/meth.2001.1262.

Maillard, J., Park, S., Croizier, S., Vanacker, C., Cook, J. H., Prevot, V., Tauber, M., \& Bouret, S. G. (2016). Loss of Magel2 impairs the development of hypothalamic Anorexigenic circuits. Human molecular genetics, 25(15), 3208-3215. https://doi.org/10.1093/hmg/ddw169.

Martin, V., Allaïli, N., Euvrard, M., Marday, T., Riffaud, A., Franc, B., Mocaër, E., Gabriel, C., Fossati, P., Lehericy, S., \& Lanfumey, L. (2017). Effect of agomelatine on memory deficits and hippocampal gene expression induced by chronic social defeat stress in mice. Scientific reports, 8, 45907. https://doi.org/10.1038/srep45907.

Matarazzo, V., \& Muscatelli, F. (2013). Natural breaking of the maternal silence at the mouse and human imprinted Prader-Willi locus: A whisper with functional consequences. Rare diseases (Austin, Tex.), 1, e27228. https://doi.org/10.4161/rdis.27228.

Meira, T., Leroy, F., Buss, E. W., Oliva, A., Park, J., \& Siegelbaum, S. A. (2018). A hippocampal circuit linking dorsal CA2 to ventral CA1 critical for social memory dynamics. Nature communications, 9(1), 4163. https://doi.org/10.1038/s41467-018-06501-w.

Meziane, H., Schaller, F., Bauer, S., Villard, C., Matarazzo, V., Riet, F., Guillon, G., Lafitte, D., Desarmenien, M. G., Tauber, M., \& Muscatelli, F. (2015). An Early Postnatal Oxytocin Treatment Prevents Social and Learning Deficits in Adult Mice Deficient for Magel2, a Gene Involved in Prader-Willi Syndrome and Autism. Biological psychiatry, 78(2), 85-94. https://doi.org/10.1016/j.biopsych.2014.11.010.

Mitchell, D. C., Bryan, B. A., Liu, J. P., Liu, W. B., Zhang, L., Qu, J., Zhou, X., Liu, M., \& Li, D. W. (2007). Developmental expression of three small GTPases in the mouse eye. Molecular vision, 13, 1144-1153. 
Muscatelli, F., Desarménien, M. G., Matarazzo, V., \& Grinevich, V. (2018). Oxytocin Signaling in the Early Life of Mammals: Link to Neurodevelopmental Disorders Associated with ASD. Current topics in behavioral neurosciences, 35, 239-268. https://doi.org/10.1007/7854_2017_16.

Naskar, S., Narducci, R., Balzani, E., Cwetsch, A. W., Tucci, V., \& Cancedda, L. (2019). The development of synaptic transmission is time-locked to early social behaviors in rats. Nature communications, 10(1), 1195. https://doi.org/10.1038/s41467-019-09156-3.

Prange, O., Wong, T. P., Gerrow, K., Wang, Y. T., \& El-Husseini, A. (2004). A balance between excitatory and inhibitory synapses is controlled by PSD-95 and neuroligin. Proceedings of the National Academy of Sciences of the United States of America, 101(38), 13915-13920. https://doi.org/10.1073/pnas.0405939101.

Raam, T., McAvoy, K. M., Besnard, A., Veenema, A. H., \& Sahay, A. (2017). Hippocampal oxytocin receptors are necessary for discrimination of social stimuli. Nature communications, 8(1), 2001. https://doi.org/10.1038/s41467-017-02173-0.

Reichova, A., Zatkova, M., Bacova, Z., \& Bakos, J. (2018). Abnormalities in interactions of Rho GTPases with scaffolding proteins contribute to neurodevelopmental disorders. Journal of neuroscience research, 96(5), 781-788. https://doi.org/10.1002/jnr.24200.

Ripamonti, S., Ambrozkiewicz, M. C., Guzzi, F., Gravati, M., Biella, G., Bormuth, I., Hammer, M., Tuffy, L. P., Sigler, A., Kawabe, H., Nishimori, K., Toselli, M., Brose, N., Parenti, M., \& Rhee, J. (2017). Transient oxytocin signaling primes the development and function of excitatory hippocampal neurons. eLife, 6, e22466. https://doi.org/10.7554/eLife.22466.

Ruhl, D. A., Bomba-Warczak, E., Watson, E. T., Bradberry, M. M., Peterson, T. A., Basu, T., Frelka, A., Evans, C. S., Briguglio, J. S., Basta, T., Stowell, M., Savas, J. N., Roopra, A., Pearce, R. A., Piper, R. C., \& Chapman, E. R. (2019). Synaptotagmin 17 controls neurite outgrowth and synaptic physiology via distinct cellular pathways. Nature communications, 10(1), 3532. https://doi.org/10.1038/s41467-019-11459-4.

Runkel, F., Rohlmann, A., Reissner, C., Brand, S. M., \& Missler, M. (2013). Promoter-like sequences regulating transcriptional activity in neurexin and neuroligin genes. Journal of neurochemistry, 127(1), 36-47. https://doi.org/10.1111/jnc.12372.

Schaaf, C. P., Gonzalez-Garay, M. L., Xia, F., Potocki, L., Gripp, K. W., Zhang, B., Peters, B. A., McElwain, M. A., Drmanac, R., Beaudet, A. L., Caskey, C. T., \& Yang, Y. (2013). 
Truncating mutations of MAGEL2 cause Prader-Willi phenotypes and autism. Nature genetics, 45(11), 1405-1408. https://doi.org/10.1038/ng.2776.

Schaller, F., Watrin, F., Sturny, R., Massacrier, A., Szepetowski, P., \& Muscatelli, F. (2010). A single postnatal injection of oxytocin rescues the lethal feeding behaviour in mouse newborns deficient for the imprinted Magel2 gene. Human molecular genetics, 19(24), 48954905. https://doi.org/10.1093/hmg/ddq424.

Sebat, J., Lakshmi, B., Malhotra, D., Troge, J., Lese-Martin, C., Walsh, T., Yamrom, B., Yoon, S., Krasnitz, A., Kendall, J., Leotta, A., Pai, D., Zhang, R., Lee, Y. H., Hicks, J., Spence, S. J., Lee, A. T., Puura, K., Lehtimäki, T., Ledbetter, D., ... Wigler, M. (2007). Strong association of de novo copy number mutations with autism. Science (New York, N.Y.), 316(5823), 445-449. https://doi.org/10.1126/science.1138659.

Urreizti, R., Cueto-Gonzalez, A. M., Franco-Valls, H., Mort-Farre, S., Roca-Ayats, N., Ponomarenko, J., Cozzuto, L., Company, C., Bosio, M., Ossowski, S., Montfort, M., Hecht, J., Tizzano, E. F., Cormand, B., Vilageliu, L., Opitz, J. M., Neri, G., Grinberg, D., \& Balcells, S. (2017). A De Novo Nonsense Mutation in MAGEL2 in a Patient Initially Diagnosed as Opitz-C: Similarities Between Schaaf-Yang and Opitz-C Syndromes. Scientific reports, 7, 44138. https://doi.org/10.1038/srep44138.

Varoqueaux, F., Aramuni, G., Rawson, R. L., Mohrmann, R., Missler, M., Gottmann, K., Zhang, W., Südhof, T. C., \& Brose, N. (2006). Neuroligins determine synapse maturation and function. Neuron, 51(6), 741-754. https://doi.org/10.1016/j.neuron.2006.09.003.

Varoqueaux, F., Jamain, S., \& Brose, N. (2004). Neuroligin 2 is exclusively localized to inhibitory synapses. European journal of cell biology, 83(9), 449-456. https://doi.org/10.1078/0171-9335-00410.

Villar-Cheda, B., Dominguez-Meijide, A., Joglar, B., Rodriguez-Perez, A. I., Guerra, M. J., \& Labandeira-Garcia, J. L. (2012). Involvement of microglial RhoA/Rho-kinase pathway activation in the dopaminergic neuron death. Role of angiotensin via angiotensin type 1 $\begin{array}{llll}\text { receptors. } & \text { Neurobiology } & \text { 268-279. }\end{array}$ https://doi.org/10.1016/j.nbd.2012.04.010.

Wang, W., Wyckoff, J. B., Goswami, S., Wang, Y., Sidani, M., Segall, J. E., \& Condeelis, J. S. (2007). Coordinated regulation of pathways for enhanced cell motility and chemotaxis is conserved in rat and mouse mammary tumors. Cancer research, 67(8), 3505-3511. https://doi.org/10.1158/0008-5472.CAN-06-3714.

Yanagisawa, H., Komuta, Y., Kawano, H., Toyoda, M., \& Sango, K. (2010). Pleiotrophin induces neurite outgrowth and up-regulates growth-associated protein (GAP)-43 mRNA 
through the ALK/GSK3beta/beta-catenin signaling in developing mouse neurons. Neuroscience research, 66(1), 111-116. https://doi.org/10.1016/j.neures.2009.10.002.

You, G. Y., Lee, J. O., Kim, J. H., Kim, N., Lee, S. K., Moon, J. W., Jie, S., Lee, H. J., Kim, S. J., Park, S. H., \& Kim, H. S. (2013). Tiam-1, a GEF for Rac1, plays a critical role in metformin-mediated glucose uptake in C2C12 cells. Cellular signalling, 25(12), 2558-2565. https://doi.org/10.1016/j.cellsig.2013.08.018.

Young, W. S., \& Song, J. (2020). Characterization of Oxytocin Receptor Expression Within Various Neuronal Populations of the Mouse Dorsal Hippocampus. Frontiers in molecular neuroscience, 13, 40. https://doi.org/10.3389/fnmol.2020.00040.

Zatkova, M., Bakos, J., Hodosy, J., \& Ostatnikova, D. (2016). Synapse alterations in autism: Review of animal model findings. Biomedical papers of the Medical Faculty of the University Palacky, Olomouc, Czechoslovakia, 160(2), 201-210. https://doi.org/10.5507/bp.2015.066.

Zatkova, M., Reichova, A., Bacova, Z., \& Bakos, J. (2019). Activation of the Oxytocin Receptor Modulates the Expression of Synaptic Adhesion Molecules in a Cell-Specific Manner. Journal of molecular neuroscience: MN, 68(2), 171-180. https://doi.org/10.1007/s12031-019-01296-x.

Zatkova, M., Reichova, A., Bacova, Z., Strbak, V., Kiss, A., \& Bakos, J. (2018). Neurite Outgrowth Stimulated by Oxytocin Is Modulated by Inhibition of the Calcium Voltage-Gated Channels. Cellular and molecular neurobiology, 38(1), 371-378. https://doi.org/10.1007/s10571-017-0503-3.

Zeidán-Chuliá, F., Rybarczyk-Filho, J. L., Salmina, A. B., de Oliveira, B. H., Noda, M., \& Moreira, J. C. (2013). Exploring the multifactorial nature of autism through computational systems biology: calcium and the Rho GTPase RAC1 under the spotlight. Neuromolecular medicine, 15(2), 364-383. https://doi.org/10.1007/s12017-013-8224-3.

Zhou, Y., Kaiser, T., Monteiro, P., Zhang, X., Van der Goes, M. S., Wang, D., Barak, B., Zeng, M., Li, C., Lu, C., Wells, M., Amaya, A., Nguyen, S., Lewis, M., Sanjana, N., Zhou, Y., Zhang, M., Zhang, F., Fu, Z., \& Feng, G. (2016). Mice with Shank3 Mutations Associated with ASD and Schizophrenia Display Both Shared and Distinct Defects. Neuron, 89(1), 147162. https://doi.org/10.1016/j.neuron.2015.11.023. 


\section{Figure legends}

\section{Fig 1: Comparative measures of neurite outgrowth of primary cultures of hippocampal} neurons isolated from P0 WT or Magel2 $^{-/}$mice in response to $1 \mu \mathrm{M}$ oxytocin or $10 \mu \mathrm{M}$ ATRA treatment at DIV9.

The effect of Magel2 deficiency, oxytocin and all-trans retinoic acid (ATRA) treatment on neurite outgrowth. Neurite length was quantified in all neurons in a visual field from the edge of the nucleus to the apical end of the neurite. The cells were plated at the density of $0.8 \times 10^{5} / \mathrm{ml}\left(\mathrm{n}=15 \mathrm{WT}\right.$ and $\mathrm{n}=7$ Magel2 $^{-/}$pups). Six coverslips per experimental group ( $\mathrm{n}$ $=198-317$ cells) and at least 7 areas of interest per coverslip were evaluated. The average value of the longest neurite is shown. Means are represented on bars \pm SEM. ANOVA revealed significant differences between groups $\left(\mathrm{F}_{(5,1496)}=34.06 ; \mathrm{p}<0.0001\right)$. Tukey-Kramer post hoc revealed significantly different values marked with ${ }^{* *} \mathrm{p}<0.001 ; *^{*} \mathrm{p}<0.01 ;{ }^{*} \mathrm{p}<$

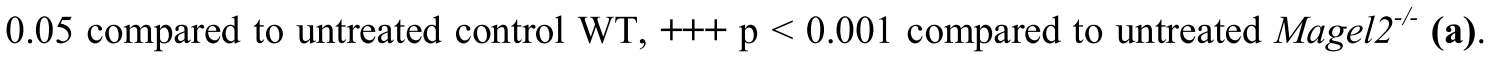
Stacked bar graphs showing the percentage of neurons with a defined length of neurites (b). Representative fluorescent microscopic images of neurons in experimental groups (c). Cells were labelled for MAP2 (green) and nucleus (blue). Days in vitro (DIV).

Fig 2: Sholl analysis of neurite arborization in primary cultures of hippocampal neurons isolated from P0 WT or Magel $^{-/}$mice in response to $1 \mu \mathrm{M}$ oxytocin or $10 \mu \mathrm{M}$ ATRA treatments at DIV9.

A graph showing the effect of Magel2 deficiency, oxytocin and all-trans retinoic acid (ATRA) treatment. The number of neurite intersections for concentric circles with various distances away from the nucleus was calculated using Fiji/ImageJ (a). Representative binary images of neurons (b) for all experimental groups are shown ( $\mathrm{n}=40$ cells per group). The cells were plated at the density of $0.8 \times 10^{5} / \mathrm{ml}\left(\mathrm{n}=15 \mathrm{WT}\right.$ and $\mathrm{n}=7$ Magel $^{-/-}$pups $)$. Scale bar represents $50 \mu \mathrm{m}$. Days in vitro (DIV).

Fig 3: Changes in the hippocampal neurite outgrowth-associated transcript levels at P5 (a, b) and P30 (c, d) WT or Magel2 $2^{-/}$mice.

The graphs show relative mRNA expression levels normalized to Gapdh transcript. qRT-PCR was calculated by the $2^{-\triangle \Delta C t}$ Livak method (Livak \& Schmittgen, 2001). Neurite outgrowthassociated transcripts at P5 (a) and P30 (c); small GTPases and kinases at P5 (b) and P30 (d). Means are represented on bars \pm SEM ( $n=4-6 /$ group). At P5, the mRNA levels of Gap43 
$(* * * \mathrm{p}<0.001, \mathrm{df}=9, \mathrm{~T}=5.01)$, Pakl $(* * \mathrm{p}<0.01, \mathrm{df}=9, \mathrm{~T}=3.83)$, Tiam1 $(* * * \mathrm{p}<0.001, \mathrm{df}=9$, $\mathrm{T}=5.94)$ and Limk1 $\left({ }^{*} \mathrm{p}<0.05, \mathrm{df}=7, \mathrm{~T}=3.01\right)$ were significantly reduced in Magel2 ${ }^{-/}$mice compared to the WT mice. At P30, the mRNA levels of Gap43 $(* * \mathrm{p}<0.01, \mathrm{df}=10, \mathrm{~T}=3.71)$, Pak1 $(* * \mathrm{p}<0.01, \mathrm{df}=9, \mathrm{~T}=3.97), \operatorname{Map} 2(* * * \mathrm{p}<0.001, \mathrm{df}=10, \mathrm{~T}=6.62)$ and $\operatorname{Rac} 1(* * \mathrm{p}<0.01$, $\mathrm{df}=10, \mathrm{~T}=3.72$ ) were significantly lower in Magel $^{-/}$mice compared to the WT mice. At P30, Tiam1 $\left({ }^{* *} \mathrm{p}<0.01, \mathrm{df}=10, \mathrm{~T}=4.55\right)$ and Limk1 $(* * * \mathrm{p}<0.001, \mathrm{df}=10, \mathrm{~T}=6.85)$ gene expression levels increased in Magel2 $^{-/}$mice compared to the WT mice. Microtubule associated protein 2 - Map2; Growth associated protein 43 - Gap43; p21 activated kinase 1 Pak1; Ras-related C3 botulinum toxin substrate 1 - Racl; T-Lymphoma invasion and metastasis-inducing protein 1 - Tiam1; LIM domain kinase 1 - Limk1.

Fig 4: Changes in the hippocampal transcript and protein levels of RhoA and RhoB at P5 (a-d) and P30 (e-h) WT or Magel2 ${ }^{-/-}$mice

The graphs show relative mRNA expression levels (a, e) normalized to Gapdh transcript and protein levels $(\mathbf{b}, \mathbf{f})$ normalized to GAPDH protein. qRT-PCR was calculated by the $2^{-\Delta \Delta \mathrm{Ct}}$ Livak method (Livak \& Schmittgen, 2001). Representative set of Western Blot Analysis results from RHOA (c, $\mathbf{g})$ and $\mathrm{RHOB}(\mathbf{d}, \mathbf{h})$. Means are represented on bars $\pm \mathrm{SEM}(\mathrm{n}=4$ 6/group). At P5, RhoB (RHOB) mRNA $\left({ }^{*} \mathrm{p}<0.01, \mathrm{df}=9, \mathrm{~T}=4.34\right)$ and protein $\left({ }^{*} \mathrm{p}<0.05\right.$, $\mathrm{df}=6, \mathrm{~T}=2.66$ ) levels were significantly increased in Magel $^{-/}$mice compared to the WT mice. At P30, the mRNA level of $R h o A\left({ }^{*} \mathrm{p}<0.05, \mathrm{df}=10, \mathrm{~T}=3.25\right)$ was significantly lower in Magel $^{-/}$mice compared to the WT mice. Ras homolog family member-RhoA and RhoB.

Fig 5: Changes in the hippocampal presynaptic transcript levels at P5 (a, b) and P30 (c, d) WT or Magel2 $2^{-/}$mice

The graphs show relative mRNA expression levels normalized to Gapdh transcript. qRT-PCR was calculated by the $2^{-\triangle \Lambda C t}$ Livak method (Livak \& Schmittgen, 2001). Presynaptic celladhesion molecules at P5 (a) and P30 (c); synaptic vesicle molecules at P5 (b) and P30 (d). Means are represented on bars \pm SEM ( $n=4-6$ /group). At P5, the mRNA levels of Nrxn1 $\alpha$ $\left({ }^{*} \mathrm{p}<0.05, \mathrm{df}=8, \mathrm{~T}=2.99\right), \operatorname{Nrxn} 2 \beta\left({ }^{*} \mathrm{p}<0.01, \mathrm{df}=9, \mathrm{~T}=4.67\right)$, Synapsin $I\left({ }^{*} \mathrm{p}<0.05, \mathrm{df}=9\right.$, $\mathrm{T}=3.03)$ and Synaptophysin $\left({ }^{*} \mathrm{p}<0.05, \mathrm{df}=9, \mathrm{~T}=2.44\right)$ were significantly reduced in Magel2 ${ }^{-/}$ mice compared to the WT mice. At P30, Nrxn1 $\beta\left({ }^{*} \mathrm{p}<0.05, \mathrm{df}=10, \mathrm{~T}=2.99\right), \operatorname{Nrxn} 2 \alpha(* * * \mathrm{p}<$ $0.001, \mathrm{df}=10, \mathrm{~T}=5.13)$ and $\operatorname{Nrxn} 2 \beta(* * \mathrm{p}<0.01, \mathrm{df}=10, \mathrm{~T}=4.09)$ gene expression levels increased in Magel $^{-/}$mice compared to the WT mice. Neurexins - Nrxns. 
Fig 6: Changes in the hippocampal postsynaptic transcript levels at P5 (a, b) and P30 (c, d) WT or Magel2 $2^{-/}$mice

The graphs show relative mRNA expression levels normalized to Gapdh transcript. qRT-PCR was calculated by the $2^{-\Delta \Delta \mathrm{Ct}}$ Livak method (Livak \& Schmittgen, 2001). Scaffolding proteins at P5 (a) and P30 (c); postsynaptic cell adhesion molecules at P5 (b) and P30 (d). Means are represented on bars \pm SEM ( $\mathrm{n}=4-6$ /group). At P5, the mRNA level of Nlgn3 $\left({ }^{*} \mathrm{p}<0.05\right.$, $\mathrm{df}=9, \mathrm{~T}=2.57$ ) was increased in Magel2 ${ }^{-/}$mice compared to the WT mice. At P30, the mRNA levels of Shankl $(* * * \mathrm{p}<0.001, \mathrm{df}=10, \mathrm{~T}=4.60)$, Shank3 $(* * \mathrm{p}<0.01, \mathrm{df}=10, \mathrm{~T}=3.67)$, Nlgn2 $(* * * \mathrm{p}<0.001, \mathrm{df}=10, \mathrm{~T}=9.00)$ and $\operatorname{Nlgn} 3(* \mathrm{p}<0.05, \mathrm{df}=10, \mathrm{~T}=3.05)$ were significantly higher in Magel2 ${ }^{-/}$mice compared to the WT mice. At P30, Nlgn1 (**p $<0.01$, df $=10$, $\mathrm{T}=4.38$ ) gene expression level decreased in Magel2 ${ }^{-/}$mice compared to the WT mice. SH3 and multiple ankyrin repeat domains - Shanks; Neuroligins - Nlgns.

Fig 7: Changes in the hippocampal transcript and protein levels of Psd95 at P5 (a-c) and P30 (d-f) WT or Magel2 ${ }^{-/}$mice

The graphs show relative mRNA expression levels (a, d) normalized to Gapdh transcript and protein levels $(\mathbf{b}, \mathbf{e})$ normalized to GAPDH protein. qRT-PCR was calculated by the $2^{-\Delta \Delta C t}$ Livak method (Livak \& Schmittgen, 2001). Representative set of Western Blot Analysis results from PSD95 at P5 (c) and P30 (f). Means are represented on bars \pm SEM (n = 46/group). At P5, the mRNA level of $P s d 95$ (*** $\mathrm{p}<0.001, \mathrm{df}=8, \mathrm{~T}=6.15$ ) was significantly reduced in Magel2 $^{-/}$mice compared to the WT mice. At P30, PSD95 (* p $<0.05$, df $=9$, $\mathrm{T}=2.29)$ protein level increased in Magel2 $^{-/}$mice compared to the WT mice. Postsynaptic density protein 95 - Psd95.

Fig 8: Quantitative assessment of excitatory presynaptic VGLUT2 and postsynaptic PSD95 markers in primary cultures of hippocampal neurons isolated from P0 WT or Magel2 $^{-/-}$mice at DIV9

The graphs show the effect of Magel2 deficiency on excitatory presynaptic VGLUT2 (a) and postsynaptic PSD95 (b) markers. Representative fluorescent microscopic images of neurites as they were used for quantification (c, d). Quantitative analysis of the fluorescent staining of presynaptic VGLUT2-positive and PSD95-positive compartments juxtaposed to MAP2positive neurites, expressed in total quantity of fluorescence. Three individual dendritic segments $(10 \mu \mathrm{m}$ each) per neuron at least $10 \mu \mathrm{m}$ from the nucleus were randomly chosen. The scale bar represents $2 \mu \mathrm{m}$. The cells were plated at the density of $0.8 \times 10^{5} / \mathrm{ml}(\mathrm{n}=9 \mathrm{WT}$ 
and $\mathrm{n}=9$ Magel2 $^{-/}$pups). Means are represented on bars $\pm \operatorname{SEM}(\mathrm{n}=110-150$ cells). Student's t-test revealed a decrease of the total quantity of fluorescence of the VGLUT2 $(* * p$ $<0.01, \mathrm{df}=224, \mathrm{~T}=2.78)$ in Magel2 $^{-/}$compared to the WT neurons (a). Student's t-test revealed a decrease of the total quantity of fluorescence of the PSD95 $(* * * \mathrm{p}<0.001, \mathrm{df}=219$, $\mathrm{T}=6.39$ ) in Magel2 $^{-/}$compared to the WT neurons (b). Postsynaptic density protein 95 (PSD95); Vesicular Glutamate Transporter 2 (VGLUT2); Microtubule Associated Protein 2 (MAP2).

\section{Fig 9: Quantification of colocalization between VGLUT2 and PSD95 in the hippocampal areas CA1 and CA3 WT or Magel2 ${ }^{-/}$mice}

The graphs show the effect of Magel2 deficiency and oxytocin treatment on colocalization of PSD95 and VGLUT2 in the hippocampal areas CA1 (a) and CA3 (b). Representative image of chosen regions (c) and microscopic images showing immunoreactivity to PSD95/VGLUT2 (d,e). Quantification of colocalization between PSD95 and VGLUT2 was performed using the Fiji/ImageJ plugin ComDet v0.4.1. Particles were detected from three different regions of interest (ROI) in each part of the hippocampus (CA1, CA3) in both 555 and 647 channels independently with an approximate size of 2 pixels and intensity threshold of 3 SD ( $n=4$ animals/group, 10 sections of bilateral hippocampus/group, 3 ROI/ each part of the hippocampus). Colocalization was determined based on maximum distance of 1 pixel between particles. Means are represented on bars \pm SEM. In the CA1 hippocampal area (a), two-way ANOVA revealed significant differences for the factor treatment $\left(\mathrm{F}_{(1,70)}=8.294, \mathrm{p}<\right.$ $0.01)$, as well as for the interaction of factors genotype and oxytocin treatment $\left(\mathrm{F}_{(1,70)}=8.885\right.$, $\mathrm{p}<0.01)$. The Bonferroni post hoc test revealed a significant decrease $(* \mathrm{p}<0.05)$ of the PSD95/VGLUT2 colocalization in Magel2 $^{-/}$mice compared to the WT mice. Oxytocin treatment decreased the quantity of colocalized signal in both the WT $(* * * p<0.001)$ and Magel2 deficient mice $(* \mathrm{p}<0.05)$. In the CA3 hippocampal area (b), two-way ANOVA revealed a significant difference in the interaction of factors genotype and oxytocin treatment $\left(\mathrm{F}_{(1,76)}=8.420, \mathrm{p}<0.01\right)$. The Bonferroni post hoc test revealed a significant decrease in the PSD95/VGLUT2 colocalization CA3 in Magel2 deficient mice $\left({ }^{*} \mathrm{p}<0.05\right)$ compared to the WT mice. Administration of oxytocin to the WT mice decreased the quantity of colocalized PSD95/VGLUT2 signal $(* p<0.05)$. Postsynaptic Density Protein 95 (PSD95); Vesicular Glutamate Transporter 2 (VGLUT2).

Fig 10: Changes in the hippocampal Gad65 and Gad67 transcript and GAD65+ GAD67 protein levels at P5 (a-c) and P30 (d-f) WT or Magel2 $^{-/-}$mice 
The graphs show relative mRNA expression levels (a, d) normalized to Gapdh transcript and protein levels $(\mathbf{b}, \mathbf{e})$ normalized to GAPDH protein. qRT-PCR was calculated by the $2^{-\Delta \Delta C t}$ Livak method (Livak \& Schmittgen, 2001). Representative set of Western Blot Analysis results from GAD65+GAD67 at P5 (c) and P30 (f). Means are represented on bars \pm SEM (n $=4-6 /$ group). At P5, the mRNA levels of Gad65 (**p $<0.01, \mathrm{df}=9, \mathrm{~T}=4.47)$ and Gad67 (***p $<0.001, \mathrm{df}=9, \mathrm{~T}=6.00)$ were significantly increased in Magel2 ${ }^{-/}$compared to WT mice. At P30, Gad65 (**p $<0.01, \mathrm{df}=10, \mathrm{~T}=4.43), \operatorname{Gad67}(* * \mathrm{p}<0.01, \mathrm{df}=10, \mathrm{~T}=4.41)$ gene expression levels and protein level of GAD65+GAD67 $(* \mathrm{p}<0.05, \mathrm{df}=11, \mathrm{~T}=2.37)$ increased in Magel2-- mice compared to the WT mice. Glutamic acid decarboxylase - Gad. 


\begin{tabular}{|c|c|}
\hline ASD & autism spectrum disorder \\
\hline ATRA & all-trans retinoic acid \\
\hline DIV & day in vitro \\
\hline GABA & $\gamma$-aminobutyric acid \\
\hline GAD & glutamic acid decarboxylase \\
\hline GAP43 & growth associated protein 43 \\
\hline GAPDH & glyceraldehyde 3-phosphate dehydrogenase \\
\hline LIMK1 & LIM domain kinase 1 \\
\hline MAGEL & MAGE Family Member L2 \\
\hline MAP2 & microtubule associated protein 2 \\
\hline mTORC1 & mechanistic (or mammalian) target of rapamycin complex 1 \\
\hline NLGN & neuroligin \\
\hline NRXN & neurexin \\
\hline OT & oxytocin \\
\hline OXTR & oxytocin receptors \\
\hline PAK1 & p21 activated kinase 1 \\
\hline PSD95 & postsynaptic density protein 95 \\
\hline PWS & Prader-Willi Syndrome \\
\hline Rac1 & Ras-related $\mathrm{C} 3$ botulinum toxin substrate 1 \\
\hline RhoA & Ras homolog family member A \\
\hline RhoB & Ras homolog family member B \\
\hline SHANK & SH3 and multiple ankyrin repeat domains \\
\hline SYS & Schaaf-Yang Syndrome \\
\hline TIAM1 & T-cell lymphoma invasion and metastasis 1 \\
\hline TRIM27 & tripartite motif containing 27 \\
\hline USP7 & ubiquitin specific peptidase 7 \\
\hline VGLUT2 & vesicular glutamate transporter 2 \\
\hline WASH & Wiskott-Aldrich syndrome protein and SCAR homologue \\
\hline WT & wild type \\
\hline
\end{tabular}




\begin{tabular}{llll} 
Mi2KO Fw & 5'-CCCTGGGTTGACTGACTCAT-3' & to discriminate the mutant \\
M12KO Rv & 5'-TCTTCTTCCTGGTGGCTTTG-3' & allele from the WT one \\
\hline $71456 \mathrm{Fw}$ & 5'-CACTCGATCACGTATGGCTCCATCA-3' & to discriminate the \\
$71457 \mathrm{Rv}$ & 5'-GATGGCAGGCACTGACTTACATGCTG-3' & heterozygous from the
\end{tabular}

Table 1: Primer sequences for genotyping. Fw - forward; Rv - reverse.

\begin{tabular}{l|llll}
\multicolumn{1}{l}{ Name } & $\begin{array}{l}\text { Host } \\
\text { species }\end{array}$ & Dilution & Method & Product number \\
\hline anti-RHOA & Rabbit & $1: 1000$ & WB & \# 2117S; Cell Signaling, USA \\
anti-RHOB & Rabbit & $1: 500$ & WB & AB_155149; Abcam, UK \\
anti-PSD95 & Goat & $1: 500$ & WB/IHC/ICC & AB_12093; Abcam, UK \\
anti-GAPDH & Mouse & $1: 1000$ & WB & G8795; Sigma-Aldrich, Germany \\
anti-GAPDH & Rabbit & $1: 1000$ & WB & G9545; Sigma-Aldrich, Germany \\
anti-VGLUT2 & Chicken & $1: 5000$ & IHC/ICC & 135 416; Synaptic Systems, \\
& & & & Germany \\
anti-MAP2 & Mouse & $1: 2000$ & ICC & M4403; Sigma-Aldrich, Germany \\
anti-GAD65+GAD67 & Rabbit & $1: 1000$ & WB & ab11070; Abcam, UK
\end{tabular}

Table 2: Primary antibodies. ICC - Immunocytochemistry; IHC - Immunohistochemistry; WB - Western Blot Analysis; Ras homolog family member - RHO(A,B); Postsynaptic density protein 95 - PSD95; Glyceraldehyde 3-phosphate dehydrogenase - GAPDH; Microtubule Associated Protein 2 - MAP2; Vesicular Glutamate Transporter 2 - VGLUT2; Glutamic Acid Decarboxylase - GAD(65/67).

\begin{tabular}{|c|c|c|c|c|}
\hline Name & $\begin{array}{l}\text { Host } \\
\text { species }\end{array}$ & Dilution & Method & Product number \\
\hline $\begin{array}{l}\text { anti-rabbit } \\
\text { CFTM } 770\end{array}$ & Goat & $1: 5000$ & WB & SAB4600215; Sigma-Aldrich, Germany \\
\hline $\begin{array}{l}\text { anti-mouse } \\
\text { CFTM } 680 \mathrm{R}\end{array}$ & Donkey & $1: 5000$ & WB & SAB4600207; Sigma-Aldrich, Germany \\
\hline $\begin{array}{l}\text { anti-mouse } \\
\text { Alexa Fluor } 488\end{array}$ & Goat & $1: 500$ & $\mathrm{IHC} / \mathrm{ICC}$ & A-11001; Thermo Fisher Scientific, Slovakia \\
\hline $\begin{array}{l}\text { anti-goat } \\
\text { Alexa Fluor } 680\end{array}$ & Donkey & $1: 10000$ & WB & AB_175776; Abcam, UK \\
\hline $\begin{array}{l}\text { anti-goat } \\
\text { Alexa Fluor } 555\end{array}$ & Donkey & $1: 500$ & $\mathrm{IHC} / \mathrm{ICC}$ & A-21432; Thermo Fisher Scientific, Slovakia \\
\hline $\begin{array}{l}\text { anti-chicken } \\
\text { Alexa Fluor } 647\end{array}$ & Goat & $1: 500$ & $\mathrm{IHC} / \mathrm{ICC}$ & A-21449; Thermo Fisher Scientific, Slovakia \\
\hline
\end{tabular}

Table 3: Fluorescent secondary antibodies. ICC - Immunocytochemistry; IHC - Immunohistochemistry; WB - Western Blot Analysis. 


\begin{tabular}{|c|c|c|c|}
\hline Name & Primers & Gen Bank & References \\
\hline \multirow{2}{*}{ Gad65 } & Fw: CATGGTCATCTCAAACCCTGC & \multirow{2}{*}{ L16980.1 } & \multirow{2}{*}{ (Du et al., 2017) } \\
\hline & Rv: CGAGGCGTTCGATTTCTTCA & & \\
\hline \multirow{2}{*}{ Gad67 } & Fw: GACCAATCTCTGTGACTCGCTTAG & \multirow{2}{*}{ ВC027059.1 } & \multirow{2}{*}{ (Du et al., 2017) } \\
\hline & Rv: CTGGTCAGTGTATCGGAGGTCTT & & \\
\hline \multirow{2}{*}{ Gap43 } & Fw: GTGCTGCTAAAGCTACCACT & \multirow{2}{*}{ NM_008083.2 } & \multirow{2}{*}{$\begin{array}{l}\text { (Yanagisawa et al. } \\
2010 \text { ) }\end{array}$} \\
\hline & Rv: CTTCAGAGTGGAGCTGAGAA & & \\
\hline \multirow{2}{*}{ Gapdh } & Fw: CGGTGCTGAGTATGTCGTGGAGTC & \multirow{2}{*}{ NM_001289726.1 } & \multirow{2}{*}{$\begin{array}{l}\text { (Arsenault et al. } \\
\text { 2016) }\end{array}$} \\
\hline & Rv: CTTTTGGCTCCACCCTTCAAGTG & & \\
\hline \multirow{2}{*}{ Limkl } & Fw: ATCACAGAGTACATCAAGGGC & \multirow{2}{*}{ NM_010717.3 } & \multirow{2}{*}{ (Dorval et al., 2012) } \\
\hline & Rv: GTTCATCGAATGGAGGTAGGC & & \\
\hline \multirow{2}{*}{ Map2 } & Fw: TCAGGAGACAGGGAGGAGAA & \multirow{2}{*}{ BC150945.1 } & \multirow{2}{*}{ (Martin et al., 2017) } \\
\hline & Rv: GTGTGGAGGTGCCACTTTTT & & \\
\hline \multirow{2}{*}{ Nlgn1 } & Fw: GGGGATGAGGTTCCCTATGT & \multirow{2}{*}{ NM_138666.4 } & \multirow{2}{*}{$\begin{array}{l}\text { (Kawanai et al., } \\
\text { 2016) }\end{array}$} \\
\hline & Rv: GGTTGGGTTTGGTATGGATG & & \\
\hline \multirow{2}{*}{ Nlgn 2} & Fw: AGGTGACCCTGAACGCATCA & \multirow{2}{*}{ NM_001364137.1 } & (Kawanai et al., \\
\hline & Rv: AGCAGCCGCGTGTACTTGAG & & 2016) \\
\hline Nlon 3 & Fw: CAGGCAACATGATTGATGGCAGTGT & NM 1729324 & (Runkel et al 2013) \\
\hline Nighs & Rv: GAAGGCAATATTCTCACTCACCCAGCGA & N1V1_1/2932.4 & (Kunkel el al., 2015) \\
\hline Nrxnla & Fw: CCACAACGGGCTACACGCAAGAAG & NM 020252.3 & (Kawanai et al., \\
\hline Nrontate & Rv: GCAAGTCGCGATAATTCCAGCCT & 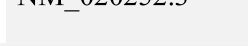 & 2016) \\
\hline$n l \beta$ & Fw: CCATGGCAGCAGCAAGCATCATTCA & NM 001346959.1 & (Runkel et al. 2013) \\
\hline Trentp & Rv: CGTGTACTGGGGCGGTCATTGGGA & 1010__001340959.1 & 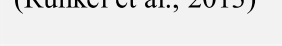 \\
\hline & Fw: CTACCTTCTGCTGGACATGGGCTCC & NM 001205234.2 & (Runkel et al., 2013) \\
\hline Nrxnza & Rv: GCGTGCTGCGGCTGTTCACA & NIV__00120J234.2 & (Nuाket et al., 201J) \\
\hline $\operatorname{Nrxn} 2 \beta$ & Fw: GTCTCGTCCAGCCTCAGCACCACC & NM 0012052352 & (Runkel et al., 2013) \\
\hline Nronzp & Rv: CGTGTACTGGGCCGGTCATTGGGA & 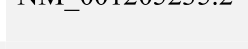 & 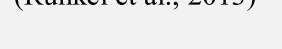 \\
\hline & Fw: GGTGCTTCAGGCACAGTGTA & NM 0110352 & (Wang et al 2007) \\
\hline Faki & Rv: TCCCTCATGACCAGGATCTC & 1NIVI_01105J.2 & (wranget di., 2000 ) \\
\hline & Fw: TCTGTGCGAGAGGTAGCAGA & NM 007864.3 & (Martin et al. 2017) \\
\hline Psd95 & Rv: AAGCACTCCGTGAACTCCTG & NIVI_00/804.J & (Mrartin el al., 2017) \\
\hline Racl & Fw: CTGCCTGCTCATCAGTTACACG & NM 0013475301 & (Mitchell et al.. 2007) \\
\hline Nact & Rv: GGACAGAGAACCGCTCGGATA & 1010_-00104/350.1 & 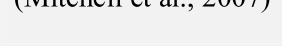 \\
\hline & Fw: TGCTTGCTCATAGTCTTCAG & JN971019.1 & (Villar-Cheda et al., \\
\hline KnOA & Rv: CAGGCGGTCATAATCTTCC & JNY11019.1 & 2012) \\
\hline$R h \cap R$ & Fw: AGGACTACGATCGTTTACGGCC & AF4819431 & (Mitchell et al 2007) \\
\hline$K n O D$ & Rv: CAGCCATTCTGGGATCCGTAG & A14 401345.1 & 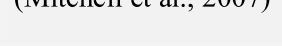 \\
\hline Shankl & Fw: CCGCTACAAGACCCGAGTCTA & NM 0010341151 & (Zhou et al 2016) \\
\hline & Rv: CCTGAATCTGAGTCGTGGTAGTT & 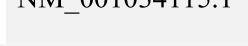 & (Z110u Cl al., 2010) \\
\hline & Fw: AGAGGCCCCAGCTTATTCCAA & AB099695.1 & (Zhou et al.. 2016) \\
\hline Shankz & Rv: CAGGGGTATAGCTTCCAAGGC & AD099095.1 & (Znou el al., 2010) \\
\hline Shank 3 & Fw: TGGTTGGCAAGAGATCCAT & NM 0214234 & (Bozdagi et al 2010) \\
\hline Nrmanins & Rv: TTGGCCCCATAGAACAAAAG & 10101_021725.T & 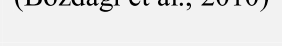 \\
\hline Synansin I & Fw: CACCGACTGGGCAAAATACT & NM 001110780.1 & (Martin et al.. 2017) \\
\hline Synapsin I & Rv: TCCGAAGAACTTCCATGTCC & NIV__001110/00.1 & (IMrattil et al., $201 /)$ \\
\hline Sunantonhysin & Fw: TCTTTGTCACCGTGGCTGTGTT & NM 0093052 & in et al 2017) \\
\hline synapiopnysin & Rv: TCCCTCAGTTCCTTGCATGTGT & NIV_009305.2 & (IVarun el al., 201/) \\
\hline Tiam1 & Fw: GTAGATGGCAGCATCGTCCT & NM_009384.3 & (You et al., 2013) \\
\hline
\end{tabular}




\section{Rv: CCTACAGGGAAGCGTGTTGT}

Table 4: Primer sequences for qRT-PCR. Fw - forward; Rv - reverse; Glyceraldehyde 3-phosphate dehydrogenase - Gapdh; Microtubule associated protein 2 - Map2; Growth associated protein 43 - Gap43; p21 activated kinase 1 - Pak1; SH3 and multiple ankyrin repeat domains - Shank(1-3); Neuroligin - Nlgn(1-3); Neurexin - Nrxn $(1 \alpha / \beta-2 \alpha \beta)$; Ras-related C3 botulinum toxin substrate 1 - Rac1; T-cell lymphoma invasion and metastasis 1 - Tiam1; LIM domain kinase 1 - Limk1; Ras homolog family member - Rho(A,B); Glutamic acid decarboxylase - Gad(65,67); Postsynaptic density protein 95 - Psd95.

\begin{tabular}{|c|c|c|c|c|c|}
\hline \multirow[b]{2}{*}{ gene } & \multirow{2}{*}{$\begin{array}{c}\text { WT } \\
\text { mRNA levels }\end{array}$} & \multicolumn{2}{|c|}{ Magel2 $^{-/-}$} & \multicolumn{2}{|c|}{ Magel2 $^{-\alpha}+$ Oxytocin } \\
\hline & & mRNA levels & statistics (df; T) & mRNA levels & statistics $(\mathrm{df} ; \mathrm{T})$ \\
\hline Nrxn1a & $1 \pm 0.08$ & $0.87 \pm 0.05 *$ & $8 ; 3.00$ & $1.10 \pm 0.10$ & $11 ; 1.08$ \\
\hline Nrxn1B & $1 \pm 0.09$ & $1.01 \pm 0.15$ & $9 ; 0.11$ & $1.39 \pm 0.11 * * *$ & $11 ; 6.74$ \\
\hline $\operatorname{Nrxn} 2 \alpha$ & $1 \pm 0.06$ & $0.92 \pm 0.14$ & $9 ; 1.17$ & $1.19 \pm 0.10 * *$ & $11 ; 4.02$ \\
\hline Nrxn2B & $1 \pm 0.09$ & $0.67 \pm 0.13 * *$ & $9 ; 4.67$ & $1.01 \pm 0.11$ & $11 ; 0.09$ \\
\hline Nlgn1 & $1 \pm 0.15$ & $0.99 \pm 0.10$ & $9 ; 0.16$ & $1.29 \pm 0.13 * *$ & $11 ; 3.57$ \\
\hline Nlgn2 & $1 \pm 0.09$ & $1.07 \pm 0.10$ & $9 ; 1.23$ & $1.52 \pm 0.11 * * *$ & $11 ; 8.91$ \\
\hline Nlgn3 & $1 \pm 0.03$ & $1.15 \pm 0.13 *$ & $9 ; 2.57$ & $1.05 \pm 0.17$ & $11 ; 0.75$ \\
\hline Psd95 & $1 \pm 0.06$ & $0.77 \pm 0.05 * * *$ & $8 ; 6.15$ & $1.10 \pm 0.19$ & $10 ; 1.31$ \\
\hline
\end{tabular}

Table 5: Changes in the hippocampal presynaptic and postsynaptic transcript levels in response to oxytocin treatment at P5 WT or Magel2 $^{-/}$mice. Values show relative mRNA levels normalized to Gapdh transcript. qRT-PCR was calculated by the $2^{-\Delta \Lambda \mathrm{Ct}}$ Livak method (51). Neurexins - Nrxns; Neuroligins - Nlgns; Postsynaptic density protein $95-$ Psd 95 . Represented are means \pm SEM ( $n=4-6 /$ group). Significantly different values are marked with $* * * \mathrm{p}<0.001 ; * * \mathrm{p}<0.01$ and $* \mathrm{p}<0.05$ compared to WT. 
a
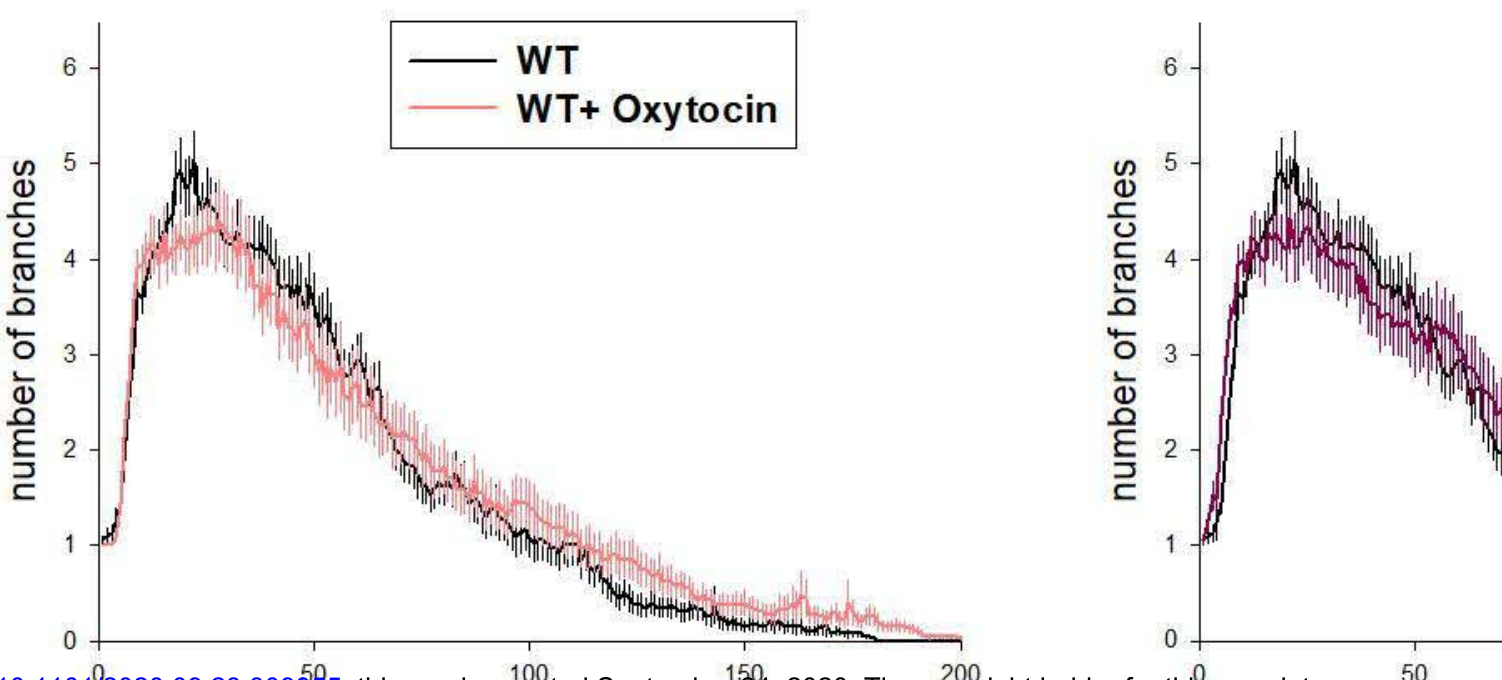

bioRxiv preprint doi: https://doi.org/10.110192020.09.23.309595; this version posted September 24 , 2020. The copyright holder for this preprint (which was not certified by peer review) is the author/funder, who has granted bioRxiv a license to display the preprint in perpetuity. It is made

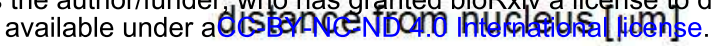

distan
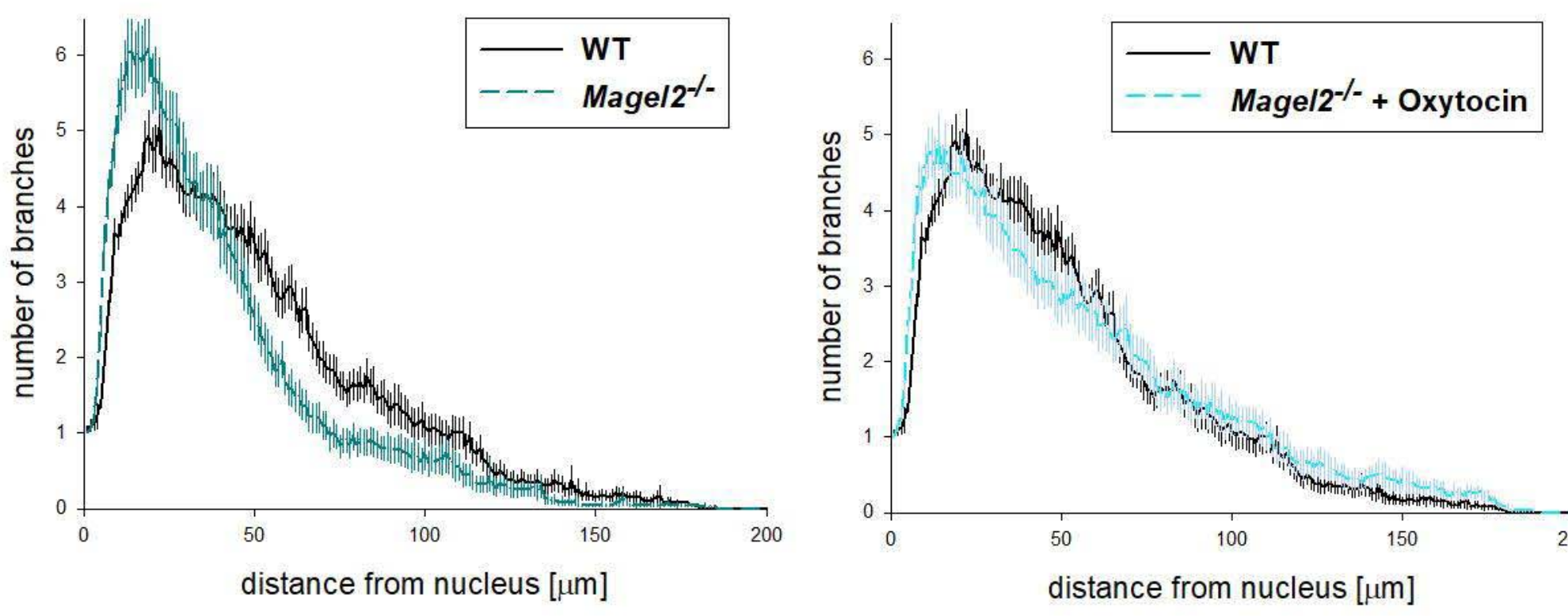

b
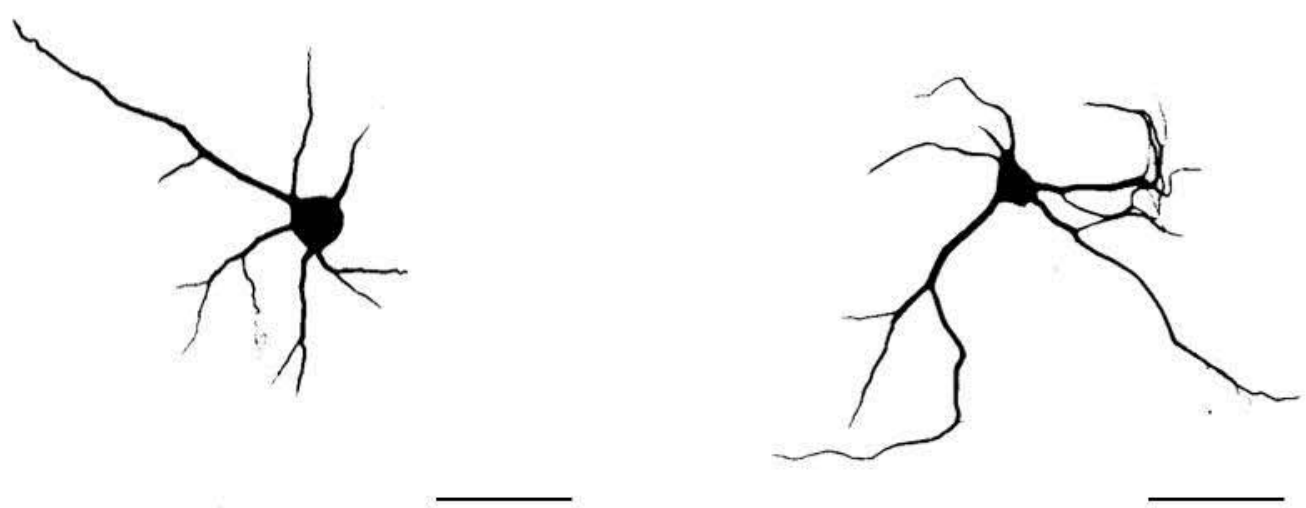
10

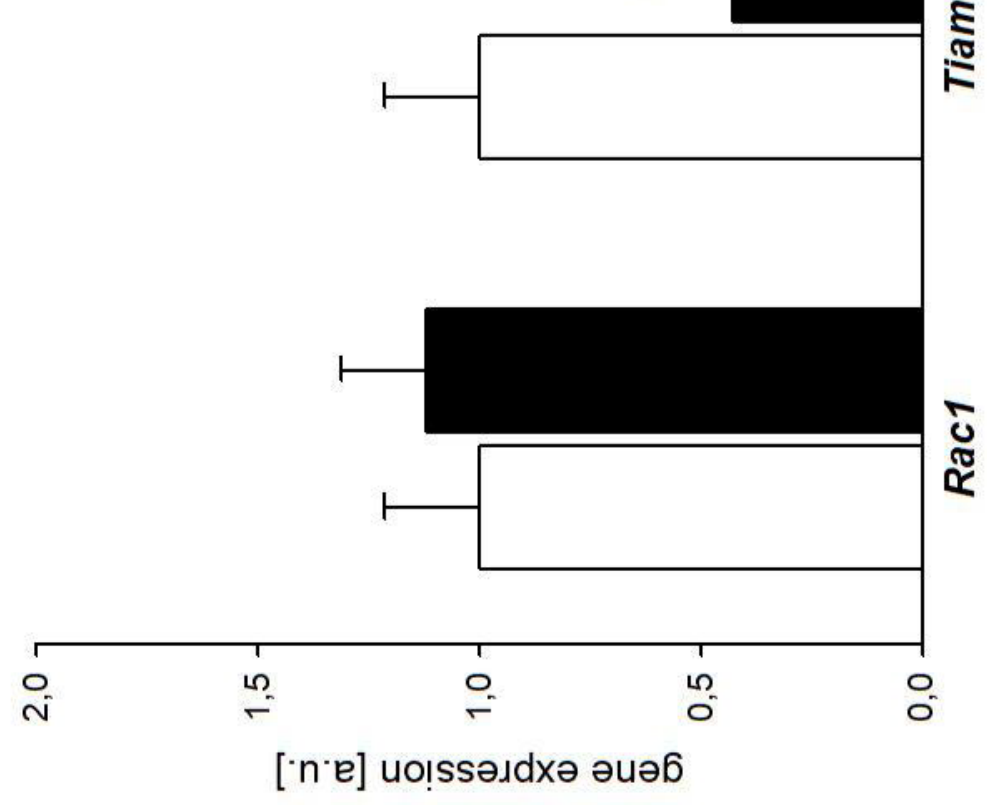

10

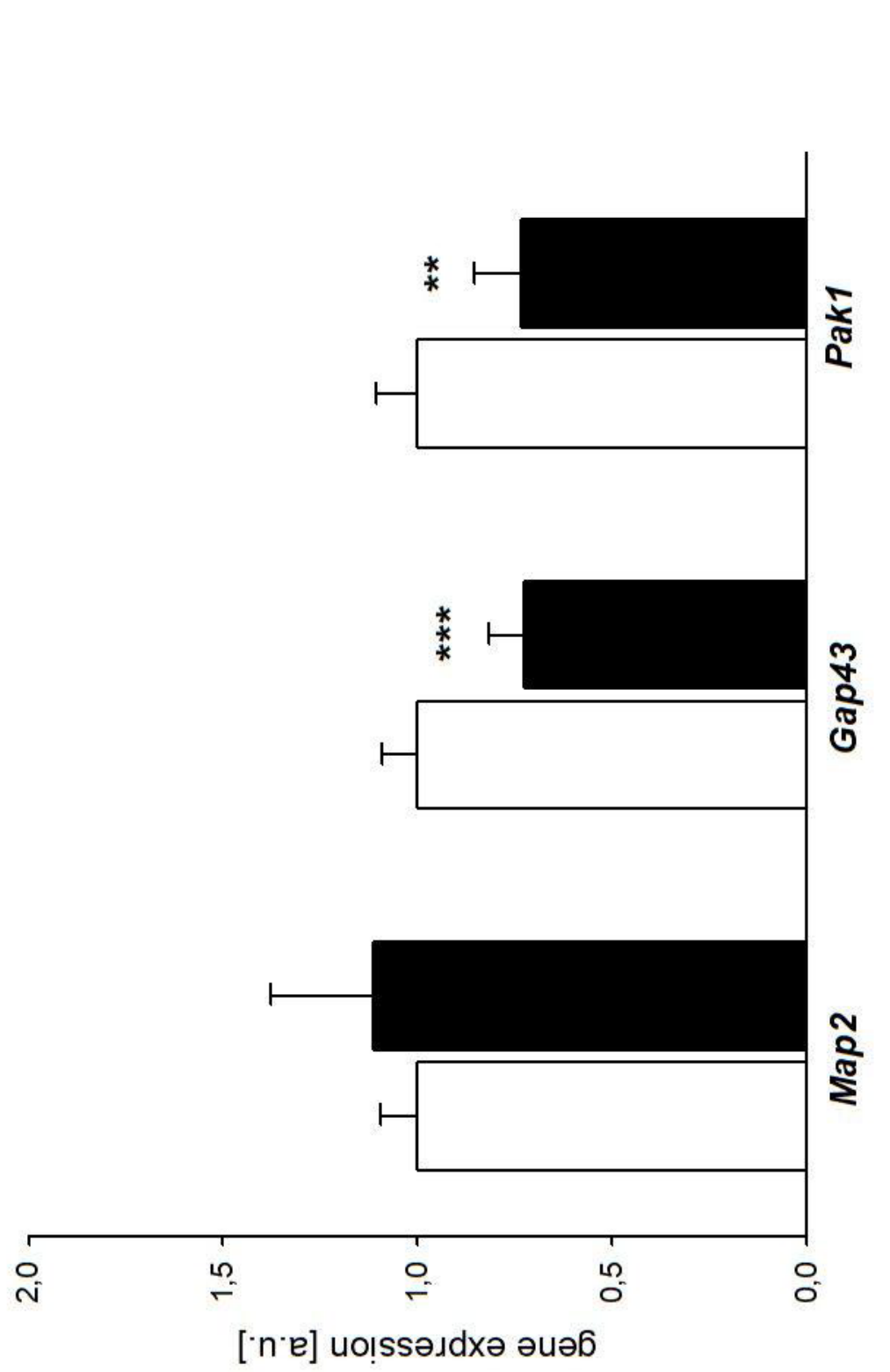

으

口

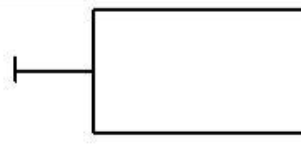

*
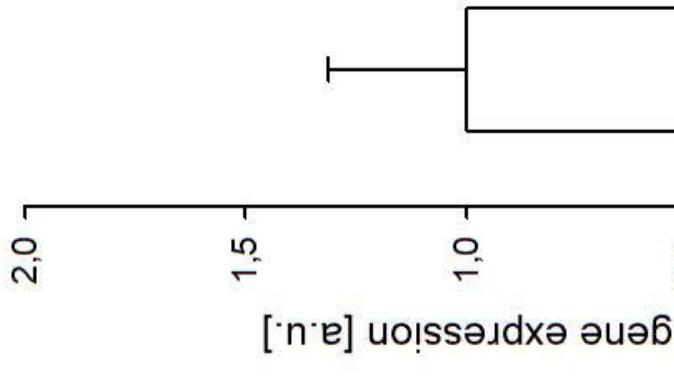

으
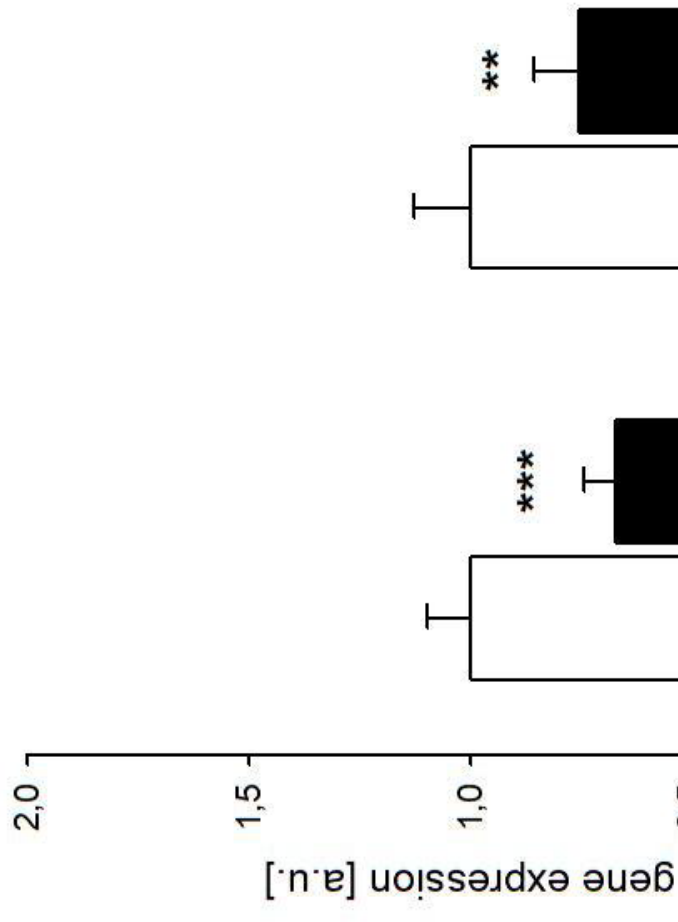


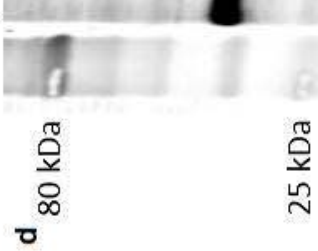

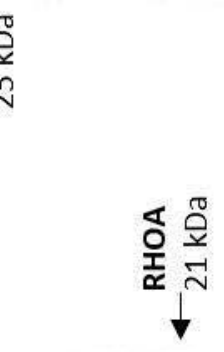

"\#/\%क्ष [ ]

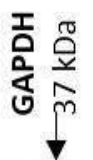

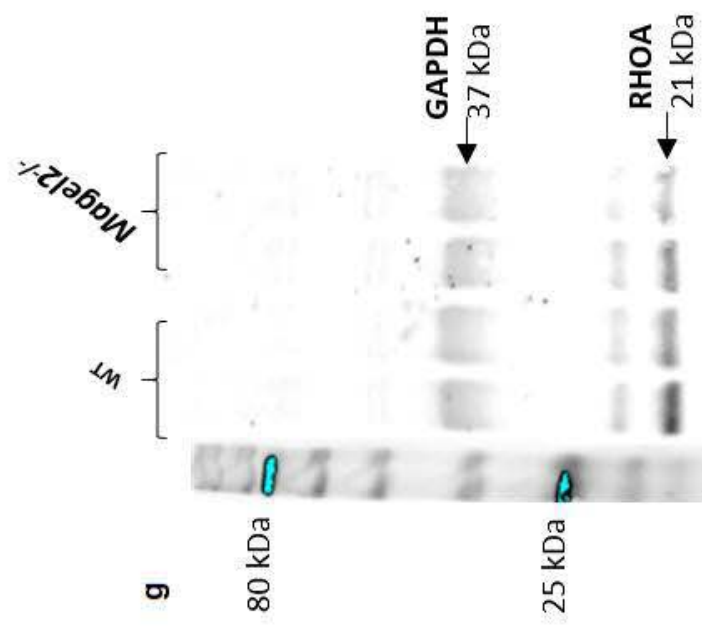

$3033 \leq 8$

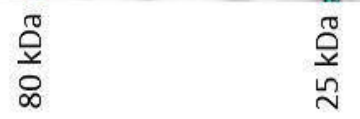

ع

농

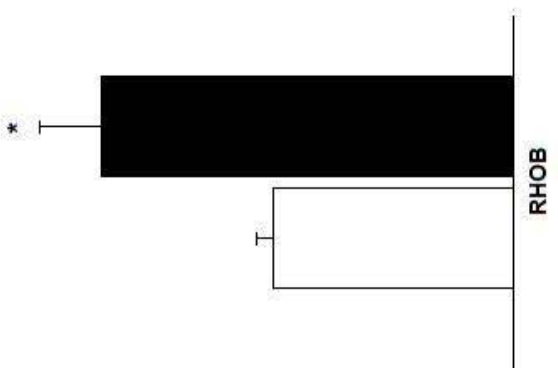

음

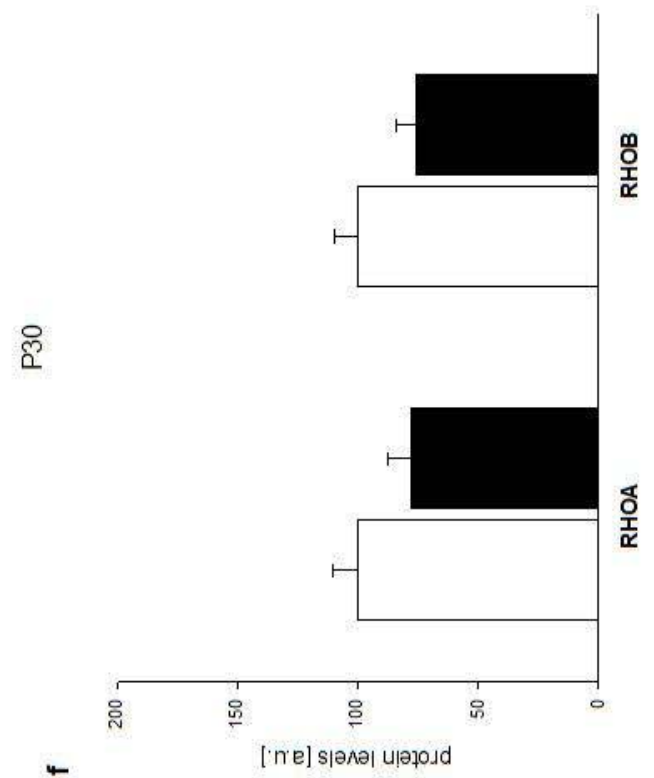

ค

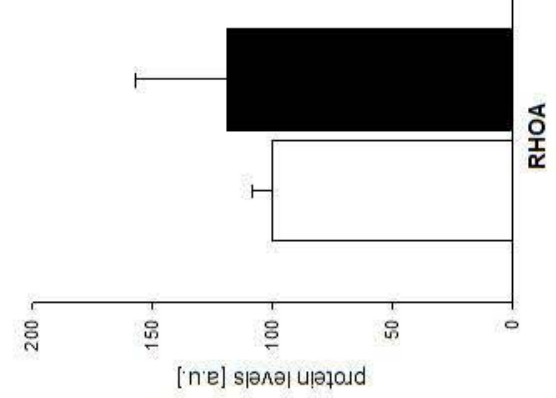

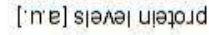

$\stackrel{\circ}{\circ}$
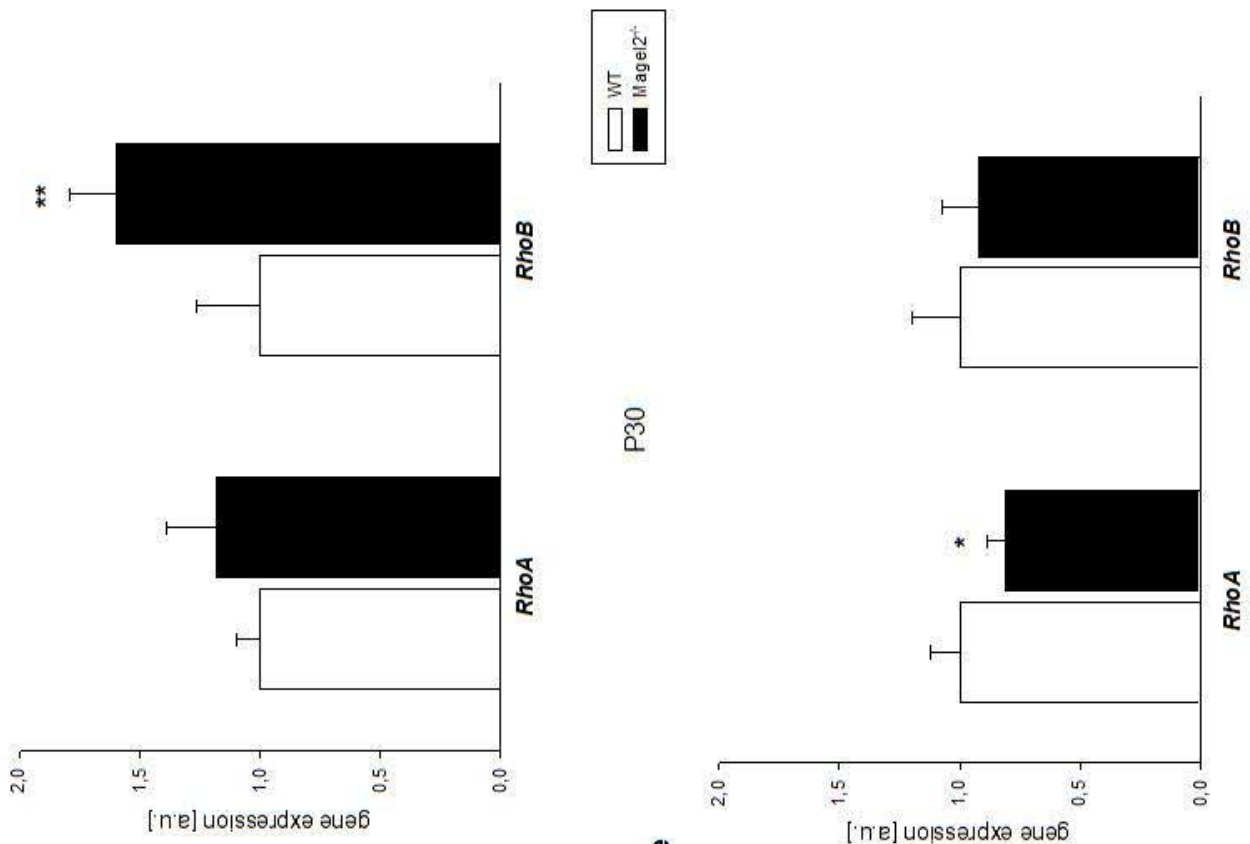

§ా

$\frac{2}{\pi}$

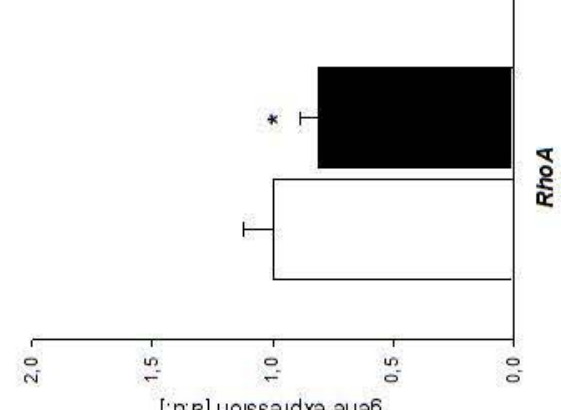

()

[n'e] uolsseddxə əuə6 
10

ฉ
으

口

ह

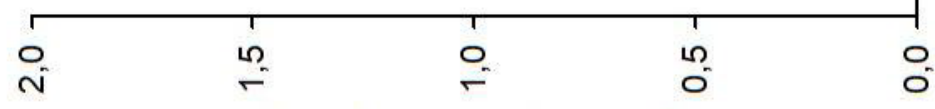

['n'e] uo!̣sรə.dxə әиәб $\stackrel{0}{0}$

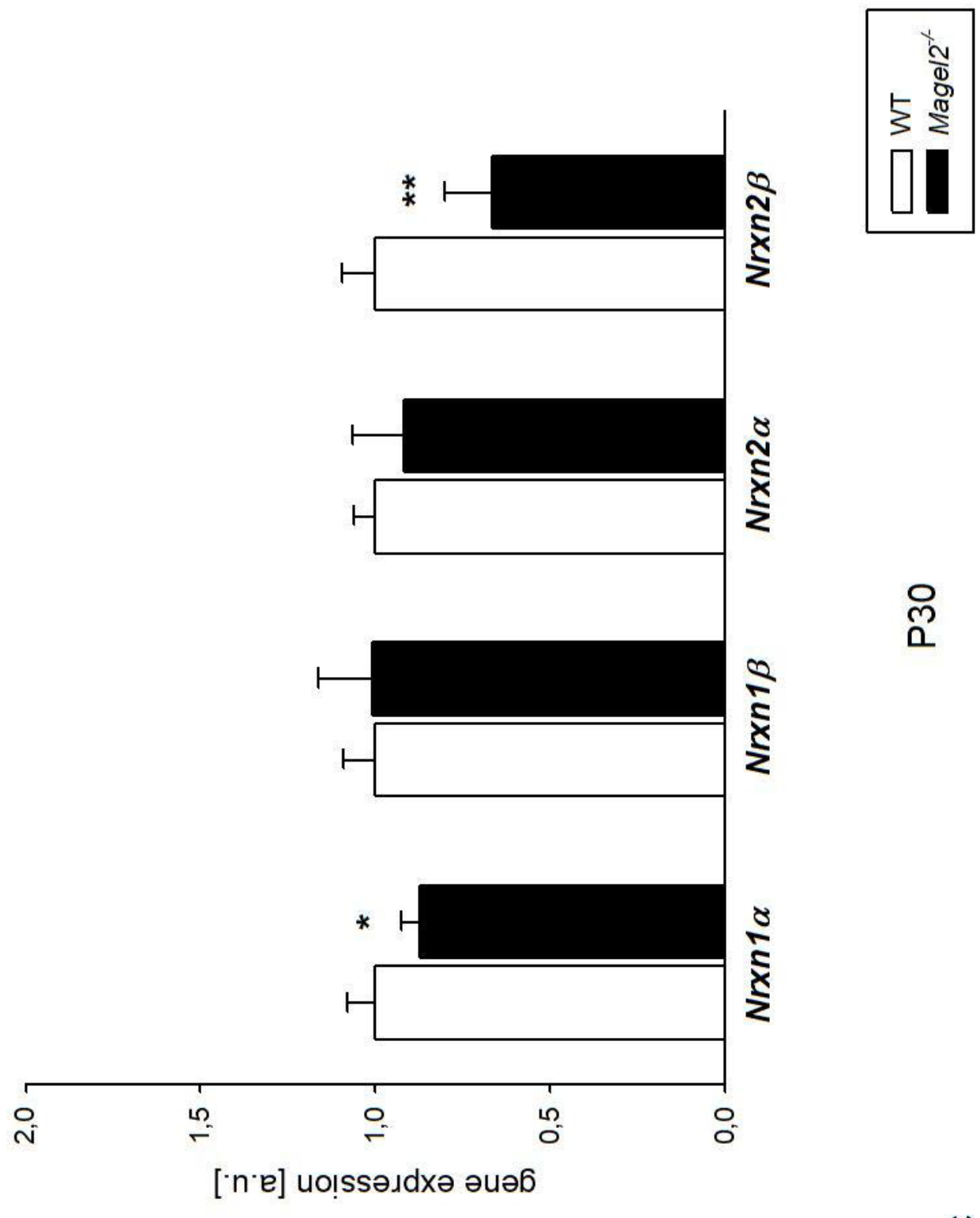

['n'e] uo!ssəגdxə әиәб
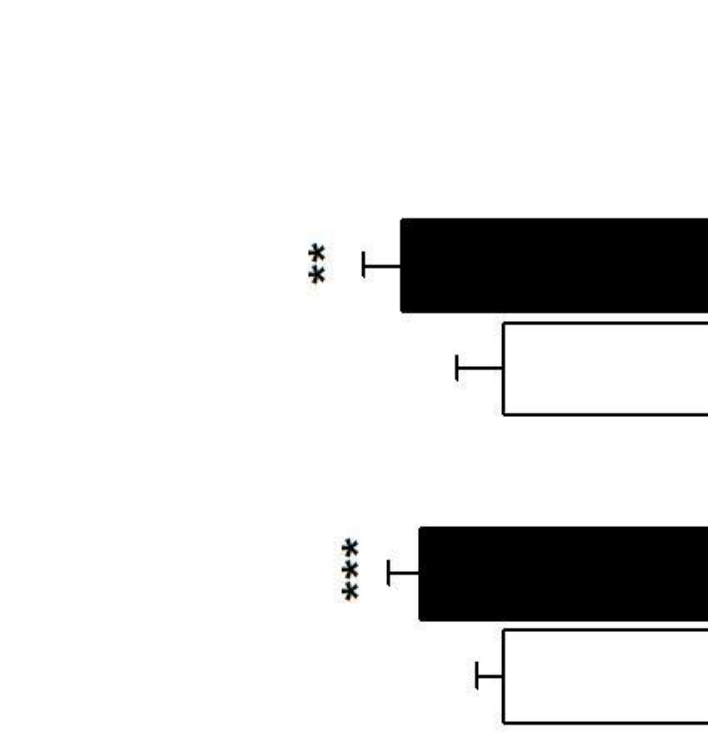

*
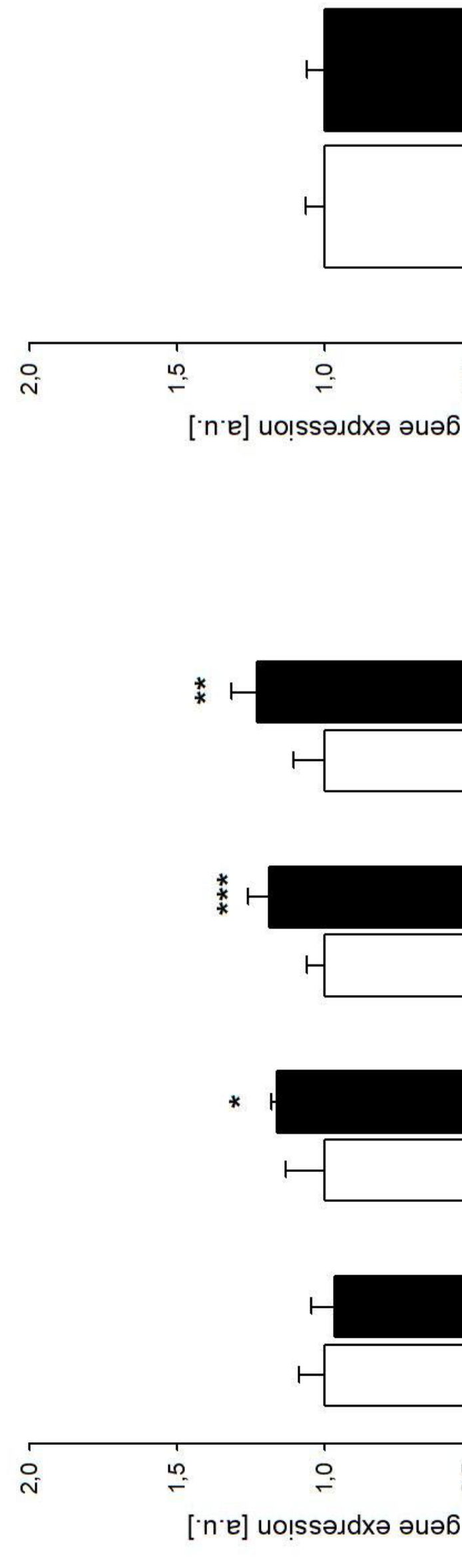
ณ

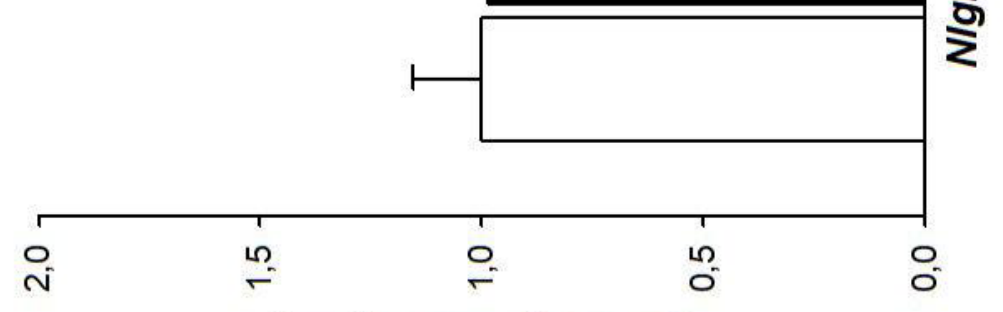

['n'e] uo!̣sรəдdxə әиә6

10

$\frac{m}{\frac{\pi}{5}}$
으

口

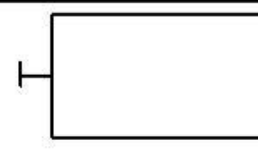

$$
\text { * }
$$

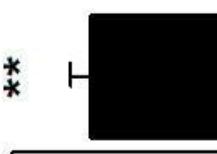

$$
\vdash
$$
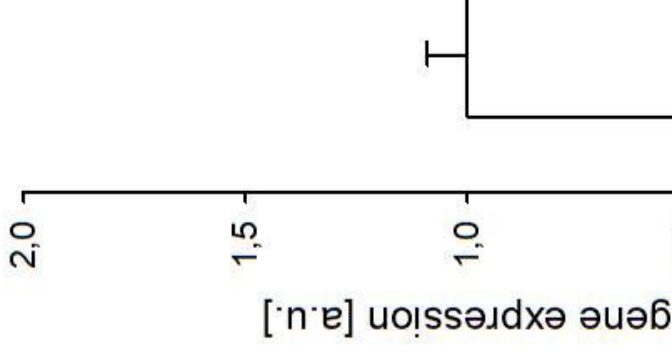

8

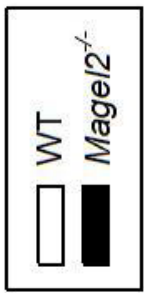

으

口
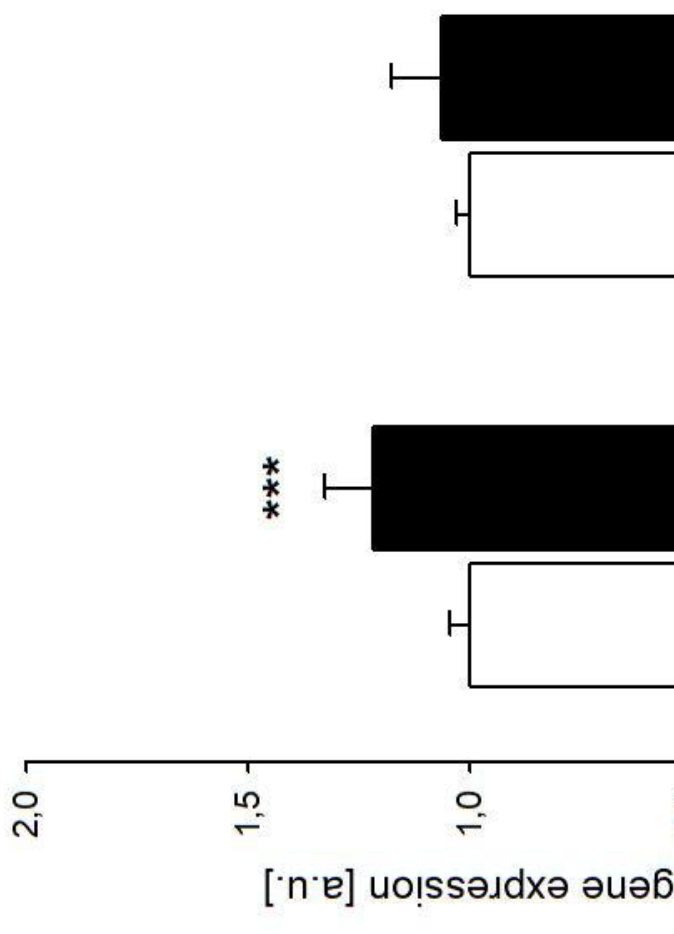


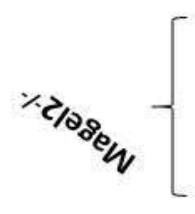

m

0

$\frac{2}{\frac{0}{2}}$

\llcorner

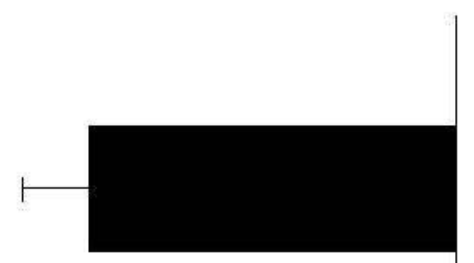

$\alpha$

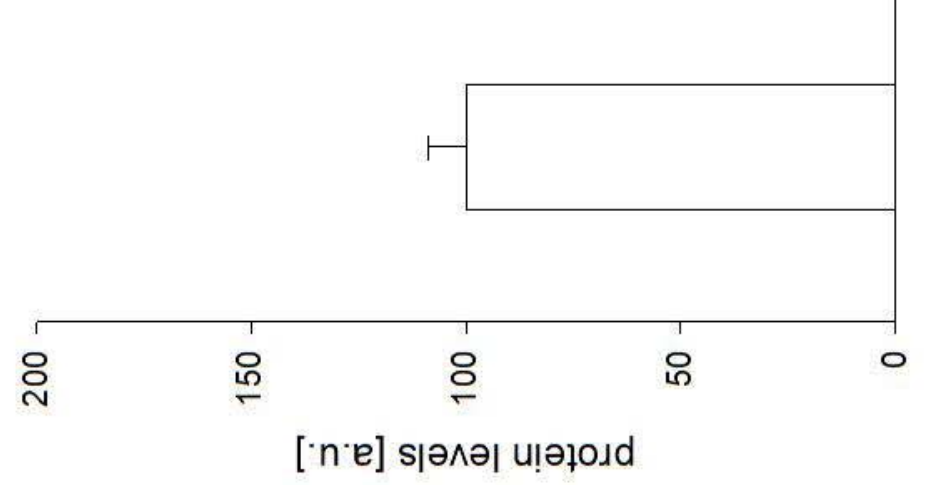

으

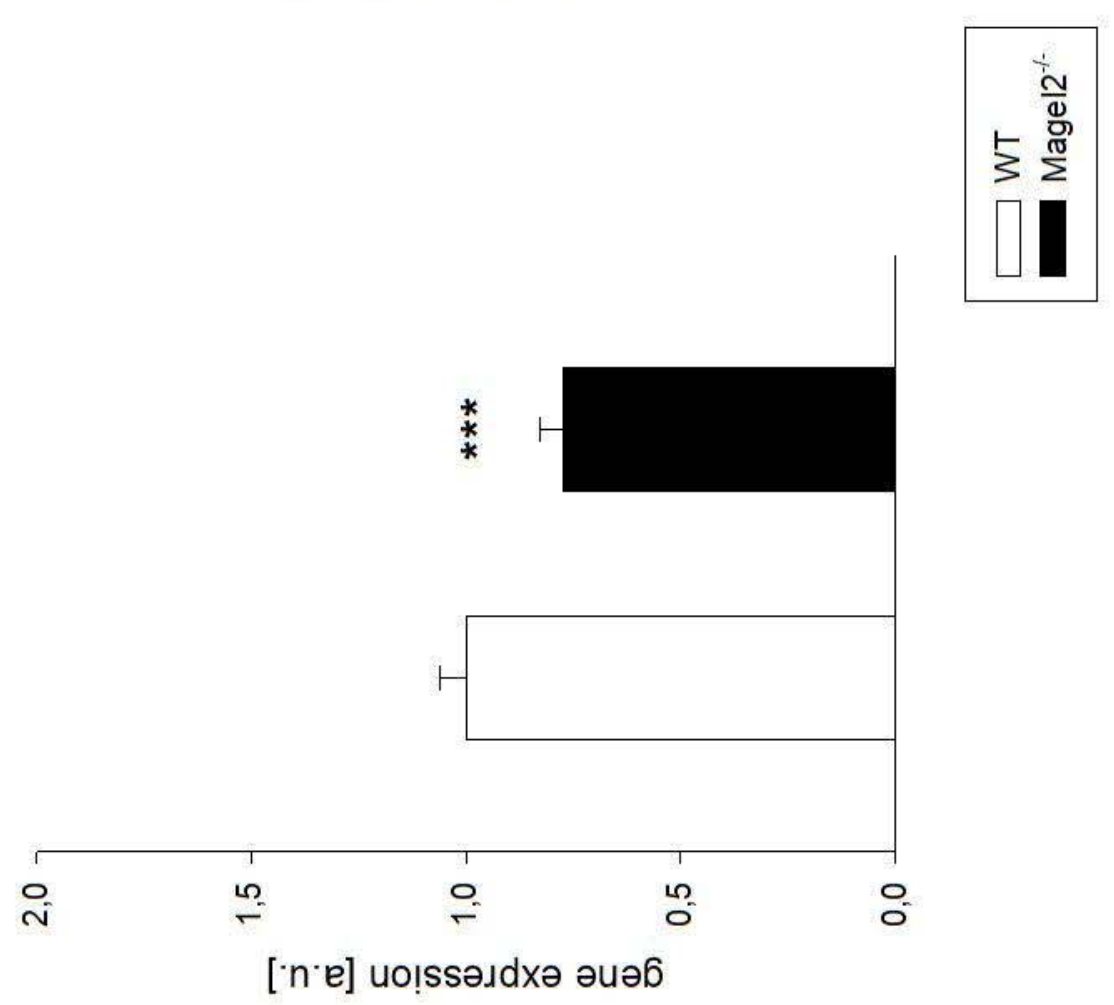

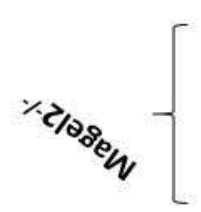

w \{

$4 \quad \frac{\frac{2}{2}}{8}$

กิ

(1)

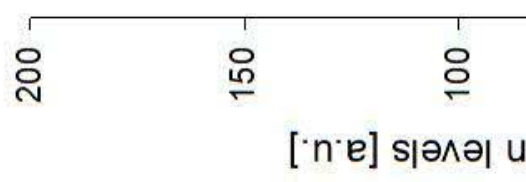

ก̊

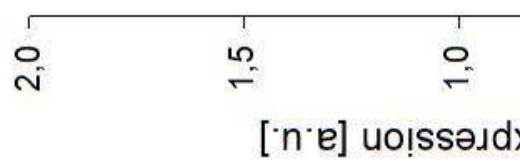

$\sigma$ 
a

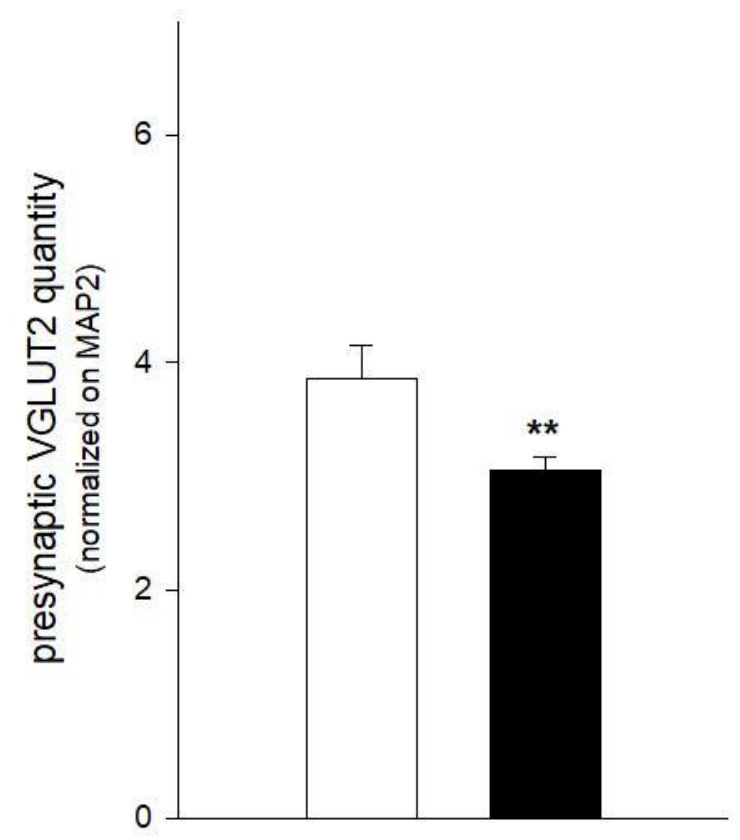

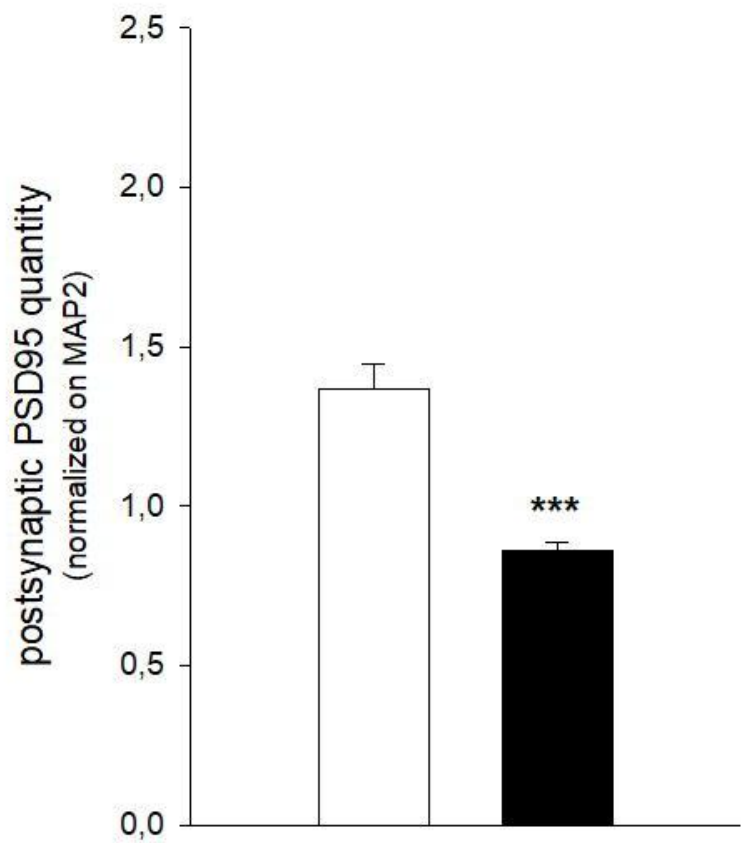
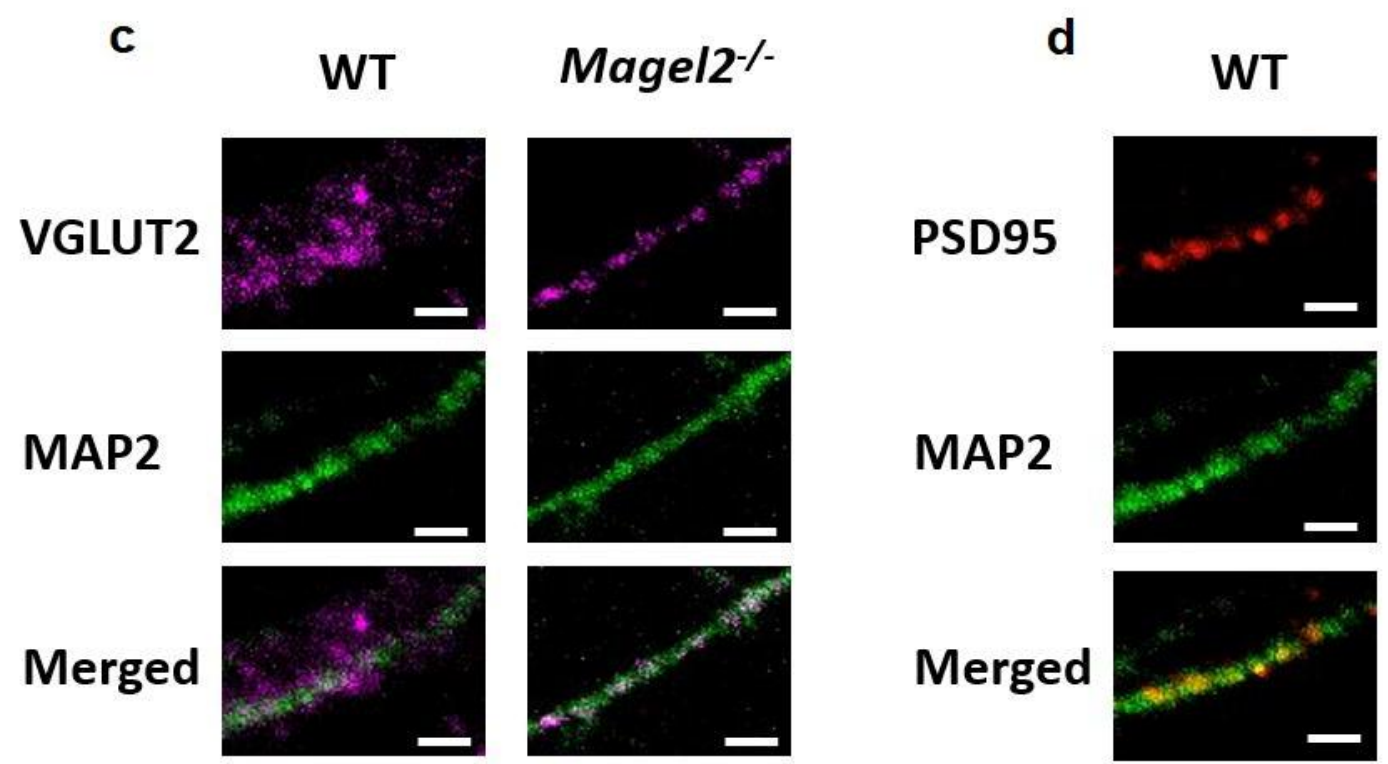

Magel2\%-

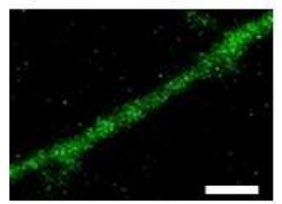

MAP2
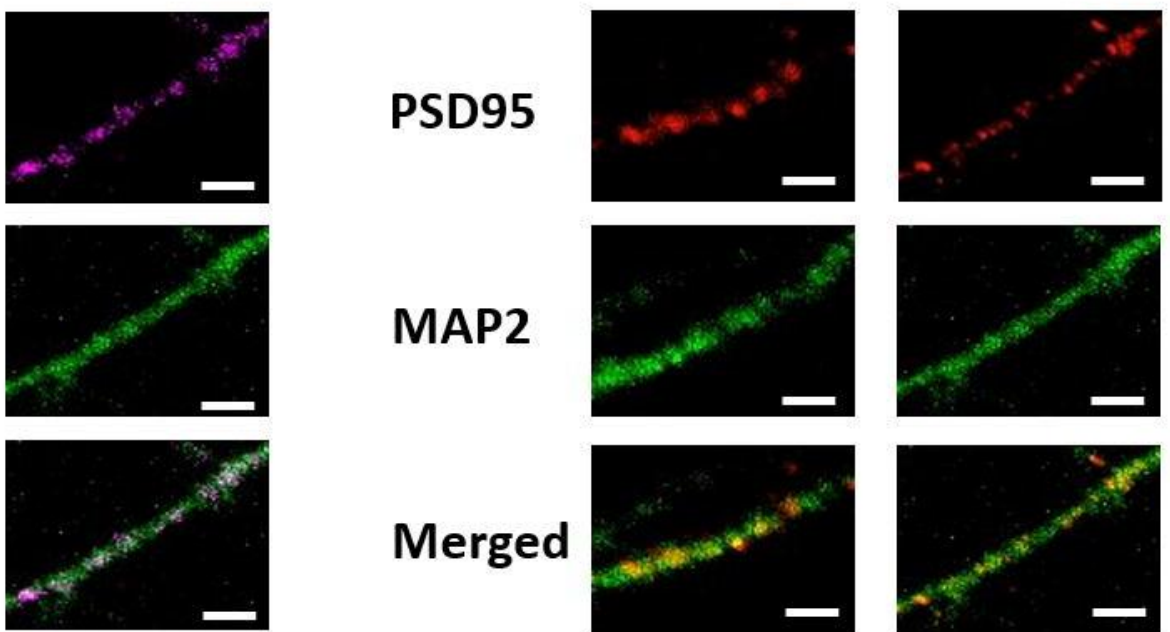

Merged
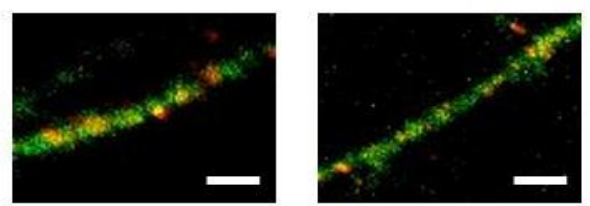
a
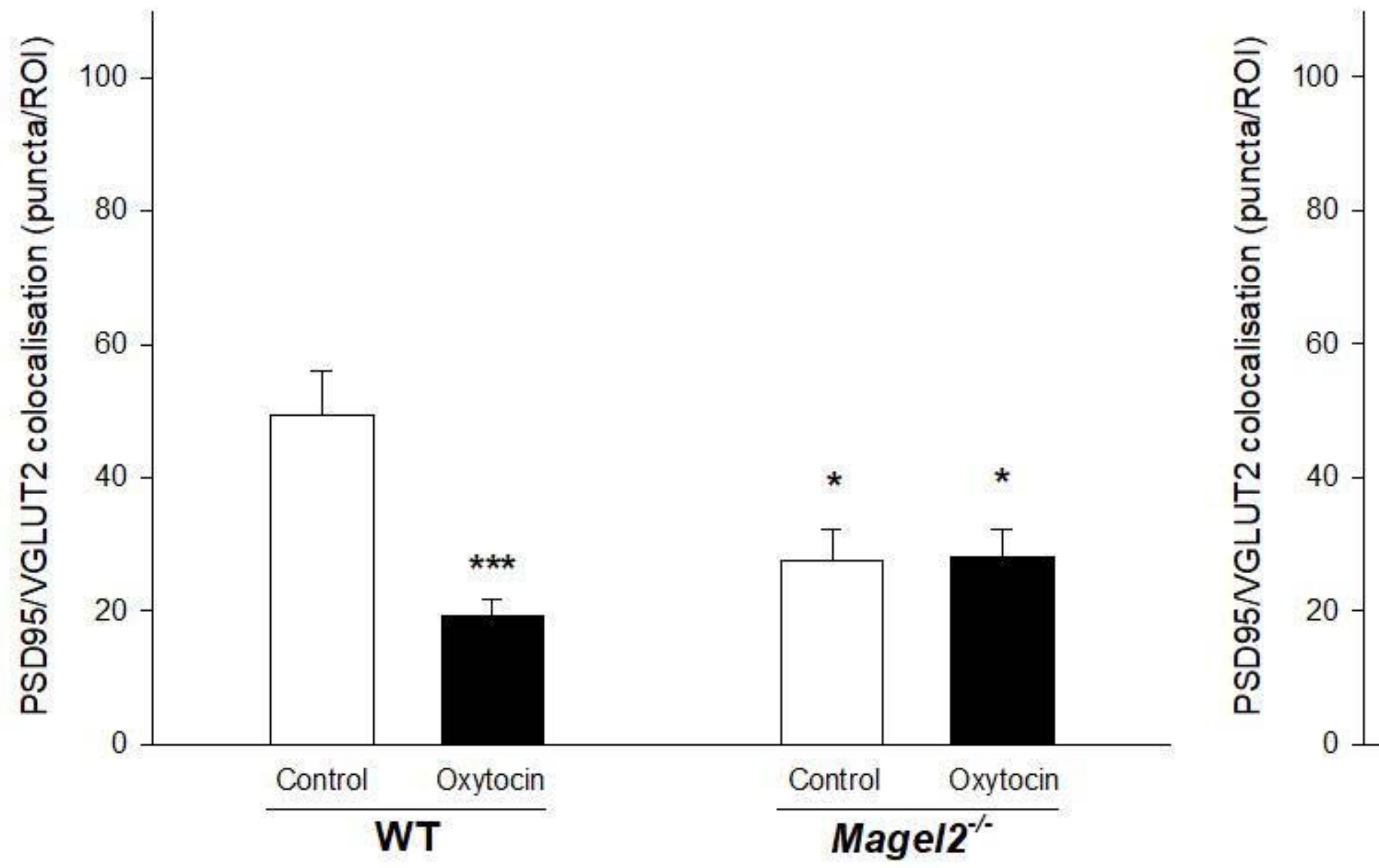

d

CA1

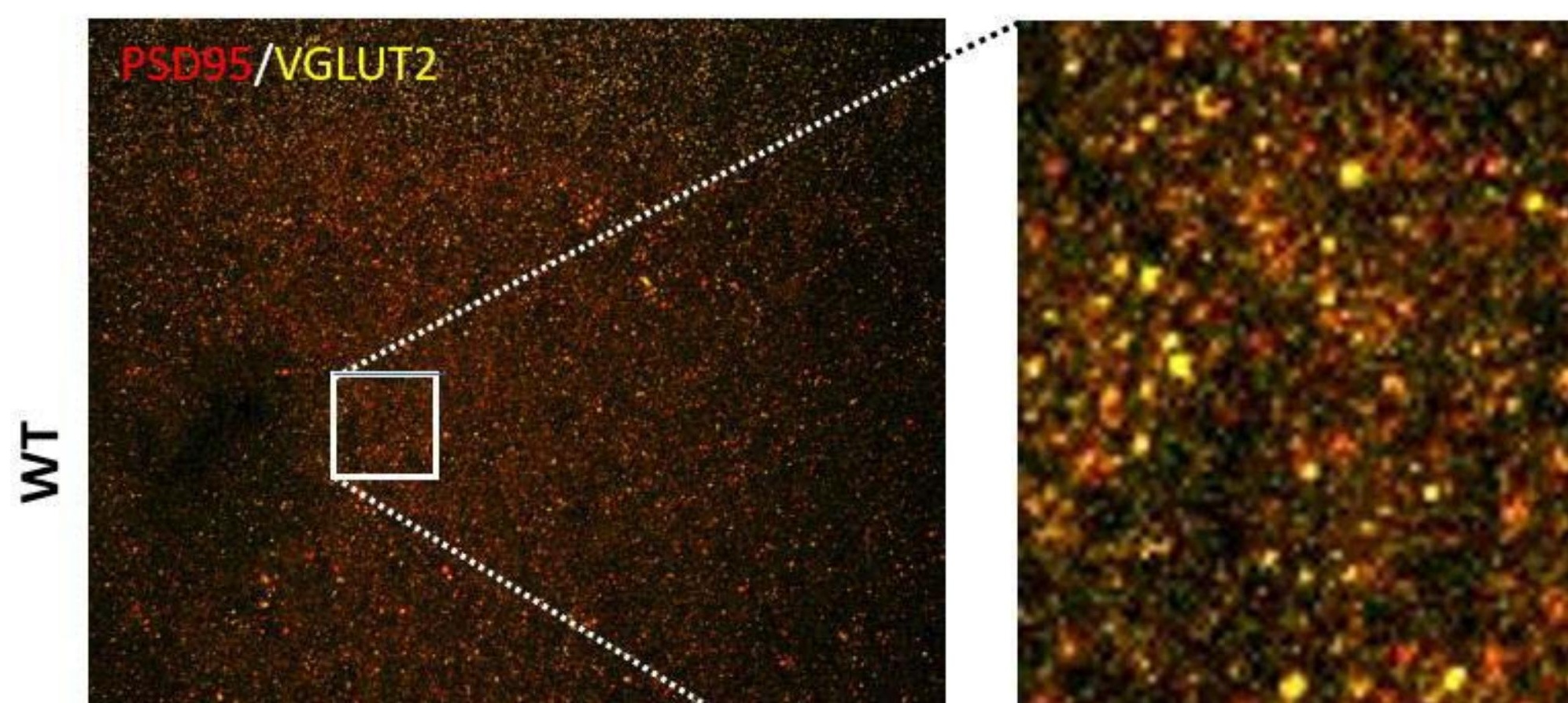




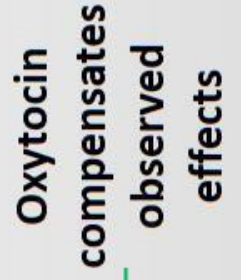
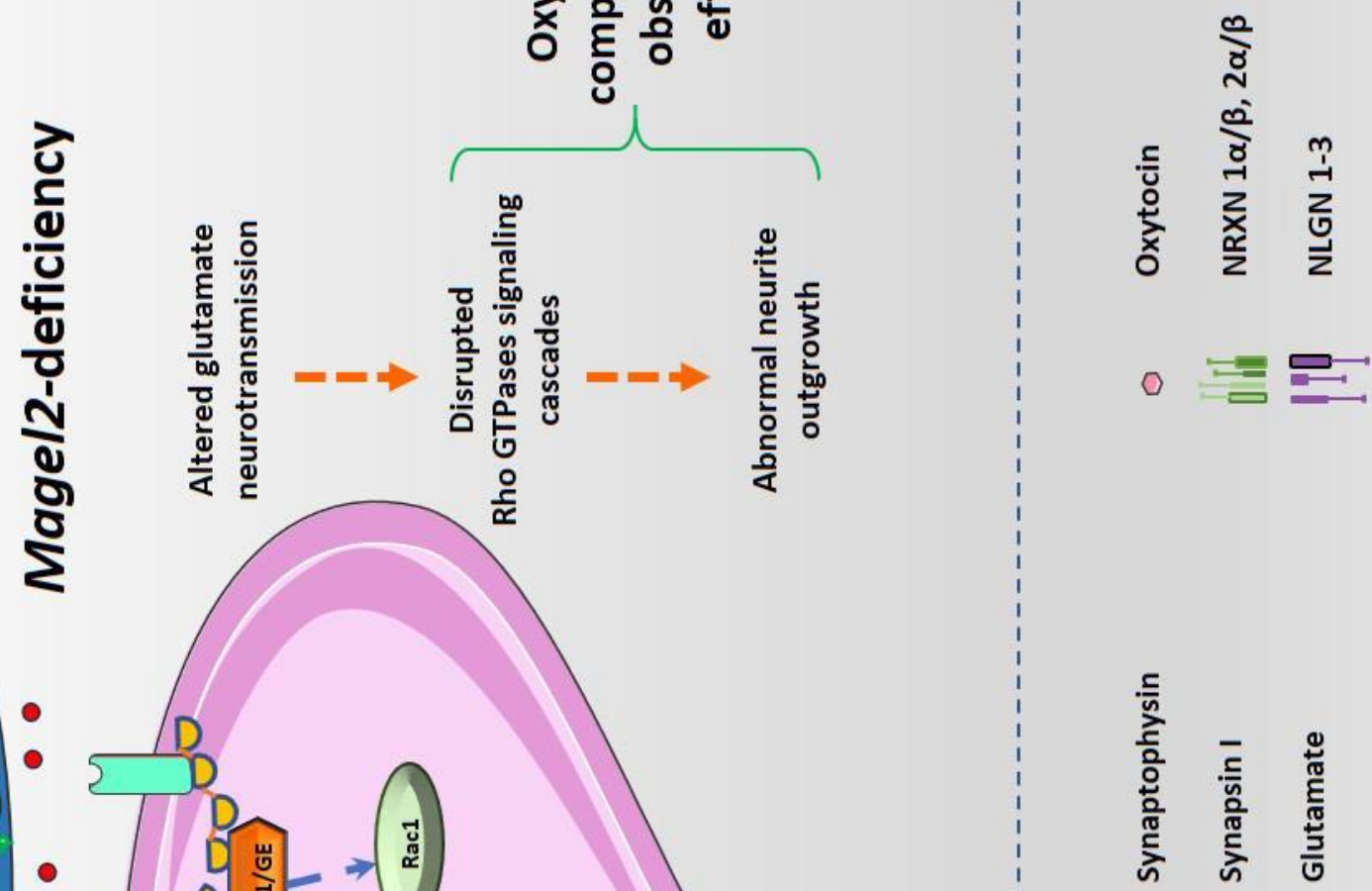

An

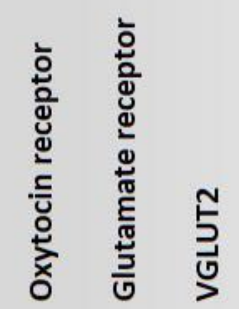

$\square 20$
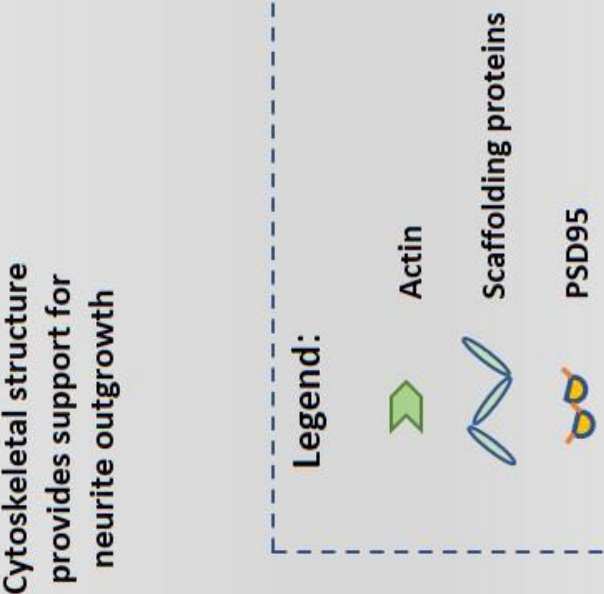

容 